\title{
Shareholder Activism on Sustainability Issues
}

\section{Citation}

Grewal, Jody, George Serafeim, and Aaron Yoon. "Shareholder Activism on Sustainability Issues." Harvard Business School Working Paper, No. 17-003, July 2016.

\section{Permanent link}

http://nrs.harvard.edu/urn-3:HUL.InstRepos:27864360

\section{Terms of Use}

This article was downloaded from Harvard University's DASH repository, and is made available under the terms and conditions applicable to Open Access Policy Articles, as set forth at http:// nrs.harvard.edu/urn-3:HUL.InstRepos:dash.current.terms-of-use\#OAP

\section{Share Your Story}

The Harvard community has made this article openly available.

Please share how this access benefits you. Submit a story.

Accessibility 


$$
\text { H A R VAR D B US INESS S C HOOL }
$$

\section{Shareholder Activism on Sustainability Issues}

Jody Grewal

George Serafeim

Aaron Yoon

Working Paper 17-003 


\title{
Shareholder Activism on Sustainability Issues
}

\author{
Jody Grewal
}

Harvard Business School

George Serafeim

Harvard Business School

Aaron Yoon

Harvard Business School

Working Paper 17-003 not be reproduced without permission of the copyright holder. Copies of working papers are available from the author. 


\title{
Shareholder Activism on Sustainability Issues
}

\author{
Jody Grewal, George Serafeim and Aaron Yoon* \\ Harvard Business School
}

\begin{abstract}
Shareholder activism on sustainability issues has become increasingly prevalent over the years, with the number of proposals filed doubling from 1999 to 2013. We use recent innovations in accounting standard setting to classify 2,665 shareholder proposals that address environmental, social and governance (ESG) issues as financially material or immaterial, and we analyze how proposals on material versus immaterial issues affect firms' subsequent ESG performance and market valuation. We find that 58 percent of the shareholder proposals in our sample are filed on immaterial issues. We document that filing shareholder proposals is effective at improving the performance of the company on the focal ESG issue, even though such proposals nearly never received majority support. Improvements occur across both material and immaterial issues. Proposals on immaterial issues are associated with subsequent declines in firm valuation while proposals on material issues are associated with subsequent increases in firm value. We show that companies increase performance on immaterial issues because of agency problems, low awareness of the materiality of ESG issues, and attempts to divert attention from poor performance on material issues.
\end{abstract}

Keywords: sustainability, shareholder activism, corporate performance, corporate social responsibility

\footnotetext{
* Jody Grewal is a doctoral student at Harvard Business School. George Serafeim is the Jakurski Family Associate Professor of Business Administration at Harvard Business School. Aaron Yoon is a doctoral student at Harvard Business School. We thank Elroy Dimson, Robert Eccles, Fabrizio Ferri, Caroline Flammer, Ioannis Ioannou, Mo Khan, and seminar participants at the University of Toronto for many helpful comments. We are grateful for financial support from the Division of Faculty Research and Development at Harvard Business School. George Serafeim has served on the Standards Council of SASB. Corresponding author: George Serafeim, Phone number: +1 6174956548 , Email: gserafeim@ hbs.edu.
} 


\section{INTRODUCTION}

A growing number of investors are now engaging companies on environmental, social and governance (ESG) issues, in addition to traditional executive compensation, shareholder rights, and board of directors' topics. ${ }^{1}$ In line with increasing engagement, shareholder proposals on ESG topics have more than doubled in the last two decades. The purpose of this paper is to test the effect that ESG proposals have on firms' subsequent ESG performance and market valuation. Critically, we use recent innovations in accounting standard setting to classify shareholder proposals that address ESG issues as financially material or immaterial, and we analyze how proposals on material versus immaterial issues affect firms' subsequent performance on the focal ESG issue and market valuation.

Past research has shown that shareholder proposals on traditional corporate governance issues, such as executive compensation, takeover provisions and board of directors' composition, have in recent years been effective at changing corporate governance, although their impact on firm valuation is unclear (Ertimur, Ferri and Muslu 2011). These proposals, although not binding, increasingly receive majority support by voting investors and as a result proxy access is being considered an important corporate governance mechanism. In contrast, there is little that is known about the efficacy of ESG shareholder proposals. Almost all of those proposals have failed to receive majority support and in most of the cases, votes in support of the proposal are below 20 percent. However, anecdotal evidence and industry practitioners suggest that ESG proposals have been important catalysts of action inside companies (Blackrock and Ceres, 2015). For example, the US Sustainable Investment Forum claims that, "often, a shareholder resolution

\footnotetext{
${ }^{1}$ For the rest of the paper we refer to ESG issues as all shareholder proposals on environmental, social and governance issues excluding issues that relate to shareholder rights, executive compensation and board of directors that have traditionally been the subject of analysis in the literature on shareholder activism. The governance issues in our sample comprise primarily political lobbying, corruption and board oversight over environmental and social issues.
} 
will fail to win a majority of the shares voted, but still succeeds in persuading management to adopt some or all of the requested changes because the resolution was favored by a significant number of shareholders." ${ }^{2}$ Moreover, while there seems to be consensus on the shareholder desirability of adopting corporate governance practices, such as increasing shareholder rights, decreasing takeover provisions, and appointing more independent directors, no such consensus within the investment community exists around ESG practices. Past research has found mixed results on the financial implications of these practices and many investors still do not take into account ESG issues in investment decisions (Kotsantonis, Pinney and Serafeim 2016).

However, the financial materiality of different sustainability issues likely varies systematically across firms and industries (Eccles and Serafeim, 2013). ${ }^{3}$ A new organization, the Sustainability Accounting Standards Board (SASB), adopts a shareholder viewpoint in defining materiality and develops standards for reporting ESG issues that distinguishes between material and immaterial issues. ${ }^{4}$ We develop a novel data set to measure the materiality of ESG proposals in ISS (formerly RiskMetrics), by hand-mapping recently-available industry-specific guidance on materiality from SASB to ISS, and then to MSCI KLD that has firm-level ratings on an array of sustainability issues. SASB considers evidence of investor interest and financial impact when determining the materiality of ESG issues, which is the same criteria used by the SEC in determining the materiality of financial information (the SASB classification process is described in more detail in Appendix I and Appendix II).

\footnotetext{
${ }^{2}$ See http://www.ussif.org/resolutions

${ }^{3}$ See for example United Nations Environment Program Finance Initiative and World Business Council for Sustainable Development. 2010. Translating environmental, social and governance factors into sustainable business value http://www.unepfi.org/fileadmin/documents/translatingESG.pdf.

${ }^{4}$ Specifically, SASB considers the information needs of the "reasonable investor" in defining materiality http://www.sasb.org/materiality/materiality-assessment/
} 
Consistent with prior literature on shareholder activism (Bebchuk, Brav and Chiang 2015), we use the standard methodology and track the industry-adjusted market valuation (i.e. Tobin's Q) over time for firms that are the subject of a shareholder proposal. We assess for the validity of a parallel trend assumption between engaged firms and the industry median and complement this research design with a propensity score matched sample of non-engaged firms that exhibit identical pre-engagement performance level and trend on the focal ESG issue and identical level and trend on Tobin's Q to that of engaged firms. We find that 58 percent of the shareholder proposals in our sample are filed on immaterial issues and that these proposals are accompanied by larger and faster increases in firms' performance on the ESG issue that the proposal identifies, relative to proposals on material issues. The high percentage of proposals on immaterial issues might not be surprising given the prosocial objectives of a large number of sponsors of such proposals. Overall, we observe that filing shareholder proposals is effective at improving the performance of the company on the focal ESG issue across both material and immaterial issues. Thus, even though such proposals have rarely received majority support, they have still had an effect on corporate management. Our finding that most of the ESG proposals focus on issues that are immaterial from a financial standpoint is in line with the U.S. Chamber of Commerce's claim that companies spend resources on issues that are financially immaterial. ${ }^{5}$

We also find that subsequent to filing ESG shareholder proposals, targeted firms experience changes in Tobin's Q. However, proposals have a substantially different effect depending on whether they relate to immaterial versus material issues. Proposals on immaterial issues are associated with subsequent declines in Tobin's Q. In contrast, proposals on material issues are associated with subsequent increases in Tobin's Q. This suggests that pressure on companies to address ESG issues that are not financially material for the firm but are relevant to

\footnotetext{
${ }^{5}$ See http://www.bna.com/us-chamber-calls-n57982063976/
} 
other stakeholders could lead to decreases in financial value, while the opposite is true for proposals on material issues. Policy experts, including former Securities and Exchange Commissioner Troy Paredes and director of the Manhattan Institute's Center for Legal Policy Jim Copland, have argued that environmental and social issues divert the attention of senior management and directors away from more important work thereby destroying value. ${ }^{6}$ We show that this position is supported when analyzing financially immaterial ESG proposals. However, our results suggest that one should be careful about overgeneralizing since a significant number of ESG proposals are financially material and associated with subsequent increases in market valuation. We find that the positive effect of proposals on material issues is present for both companies that start from low or high levels of performance on the focal sustainability issue.

One question that our results generate is why managers would improve performance on immaterial issues if doing so is associated with decreased financial value. We test different explanations as to why managers seemingly respond to proposals on immaterial issues. We find evidence of agency problems, the inability to differentiate between material and immaterial sustainability issues, and an attempt to divert attention away from poor performance on material issues, as explaining this response.

Our results contribute to the literature on the antecedents of corporate sustainability performance. Past literature has documented the importance of firm, industry and country level variables (McWilliams and Siegel, 2001; Campbell, 2007; Ioannou and Serafeim, 2012). This paper contributes evidence that shareholder activism is an important mechanism to improve firms' performance on the focal issue of the activism. Our paper provides first evidence, to our knowledge, of systematic increases in firms' ESG performance after shareholder activism. Flammer (2015) provides intriguing evidence of increases in overall ESG performance

${ }^{6}$ See http://www.bna.com/us-chamber-calls-n57982063976/ 
subsequent to close call passages of about 50 ESG proposals. However, the sample includes only a small number of proposals that received majority support, thereby leaving open for future research the question of whether the broader set of activism has impacted corporate performance on ESG issues. Further, the paper does not differentiate between material and immaterial issues, which is the focus of our paper, and rather than studying overall ESG performance, we focus on proposal-specific ESG performance (e.g. environmental performance following engagement on an environmental issue) to more directly assess the consequences of ESG activism. Importantly, this study sheds light on why managers appear to respond to shareholder proposals on immaterial issues and suggests that agency problems, the inability to identify material issues and "goodwashing" incentives contribute to this phenomenon.

Moreover, our paper contributes to a large literature that analyzes the effectiveness of shareholder proposals and activism (Gillian and Starks, 2007; Bebchuk et al., 2015; Ertimur et al., 2011). In contrast to proposals on compensation and board composition issues that were ineffective in the absence of majority vote, we find management to be responsive in our sample of non-majority vote ESG proposals.

In addition, our study provides evidence on how investor induced changes in corporate ESG performance is associated with future market valuation. While prior research suggests that changes in performance on material ESG issues are positively related to changes in future stock returns, while changes in performance on immaterial ESG issues are not correlated with future stock returns (Khan, Serafeim, and Yoon, 2016), it is not clear that these results generalize to a setting where changes in ESG performance are the result of investor activism. As Eccles et al. (2014) note, even for material sustainability issues, there is an optimal level of performance after which financial performance will start declining, absent of changes in the institutional context 
and/or firm innovation. In other words, for a utility firm, it might be financially optimal to have twenty percent of its energy for electricity generation coming from renewable resources but not forty percent. Similarly, for a mining firm, it might be optimal to spend two percent of profits on robust anticorruption systems but not five percent. It is not clear whether investors pressure firms to improve their ESG performance beyond the optimal level thereby leading to decreases in financial performance, or if firms operate below that level, even on material issues. Our evidence is consistent with investor activism leading to changes in ESG performance on material issues in a way that is on average value enhancing, suggesting that the sample of engaged firms is not operating above the optimal level. Moreover, we find that differentiating between proposals that relate to financially material versus immaterial issues yields very different results, thereby adding to the evidence on the importance of recent accounting standard innovations for reporting sustainability information (Khan et al. 2016). In contrast to Khan et al. (2016), we document that immaterial sustainability issues are associated with decreases in financial value. As a result, our study highlights how investor induced changes in ESG performance, on immaterial issues, might be fundamentally different than changes in ESG performance that are initiated by management.

\section{MOTIVATION AND LITERATURE REVIEW}

An increasing number of shareholder proposals are being filed on ESG issues, in addition to traditional corporate governance issues. In 2013, nearly 40 percent of all shareholder proposals submitted to Russell 3000 companies related to ESG issues, representing a 60 percent increase since 2003 (Proxy Voting Analytics, 2014). The topics of ESG proposals are diverse, ranging from disclosure of political contributions and compliance with human rights policies, to the adoption of a climate change policy. Average support for ESG proposals has more than doubled from 10 percent in 2003 to 21 percent in 2013, but the low levels of support relative to corporate 
governance proposals, which on average garnered 42 percent voting support in 2013, is suggestive of shareholders' skepticism about the financial materiality of ESG issues.

\section{Shareholder Activism}

Prior research has largely focused on shareholder activism on corporate governance issues. Proposals relating to board independence and executive pay, along with efforts by shareholders to remove poison pills, classified boards and supermajority antitakeover amendments from corporate charters, have been the main focus of prior studies (Gillian and Starks, 2007).

At the heart of activism is the quest for value, yet the empirical evidence is mixed regarding the effects of shareholder proposals relating to corporate governance. Shareholder proposals might be unsuccessful because their voting outcomes are very low and because they are non-binding such that the board can still refuse to adopt the proposal's recommendations even when votes in support exceed 50 percent (Bauer et al., 2015). Studies from the 1990s mostly fail to find evidence that shareholder proposals improve operating performance or influence firm policies, and document insignificant or negative stock market reactions to governance proposals (Black, 1998; Karpoff, 2001; Gillian and Starks, 2007). One notable exception is Bizjak and Marquette (1998) who find that a poison pill is three times as likely to be restructured and seven times more likely to be removed when there has been a shareholder proposal, and also documents positive abnormal stock returns associated with pill restructuring following a shareholder proposal.

In the post-Enron period, there is increasing evidence that shareholder proposals affect changes in target firms' governance structures and, in some cases, enhance firm value. For example, Guo, Kruse and Noehl (2008) document that shareholder activism in the form of shareholder proposals is an important catalyst in prompting firms to drop their staggered boards, 
which elicits positive abnormal stock price reactions. Ertimur et al. (2011) finds that the rate of implementation for compensation-related proposals is only 5 percent but increases to 32 percent when the proposal receives a majority vote, and documents that firms with excess CEO pay before being engaged decrease total CEO pay on average by 38 percent. Thomas and Cotter (2007) and Ertimur et al. (2010) document that after 2002 boards have become significantly more responsive to shareholder proposals winning majority votes, resulting in directors being increasingly willing to remove important anti-takeover defenses, such as the classified board and poison pill, in response to shareholders' requests. However, despite the increase in support for shareholder proposals and board action in response, these studies find little evidence of any effect on firm value.

\section{Sustainability and Financial Performance}

The prior academic literature on the financial performance implications of sustainability investments has adopted a number of different viewpoints. One viewpoint is that such investments are efficient from shareholders' perspective. For example, enhanced sustainability performance could lead to obtaining better resources (Cochran and Wood, 1984; Waddock and Graves, 1997), higher quality employees (Turban and Greening, 1997), and better marketing of products and services (Moskowitz, 1972; Fombrun, 1996). It could also mitigate the likelihood of negative regulatory, legislative or fiscal action (Freeman, 1984; Berman et al., 1999; Hillman and Keim, 2001), while protecting and enhancing corporate reputation (Fombrun and Shanley, 1990; Fombrun, 2005; Freeman et al., 2007). A number of papers provide empirical evidence consistent with sustainability investments creating financial value. Eccles et al. (2014) identify a set of firms that adopted corporate policies related to environmental and social issues before the adoption of such policies became widespread, and find that these firms outperform their peers in 
the future in terms of stock market and accounting performance. Borgers et al. (2013) find that firms with better sustainability performance have higher risk-adjusted returns in the future (but that this result has reversed in more recent years).

A second viewpoint is that sustainability investments disproportionately raise a firm's costs, creating a competitive disadvantage in a competitive market (Friedman, 1970; Aupperle et al., 1985; McWilliams and Siegel, 1997; Jensen, 2002). One reason for making such inefficient investments could be that managers capture private benefits (Brammer and Millington, 2008; Cheng, Hong, and Shue, 2014). Another reason for making such inefficient investments could be managers' political beliefs (De Giuli and Kostovetsky, 2014).

There is mixed evidence in the prior literature on the relation between sustainability and financial performance (Barnett and Salomon, 2006; Margolis and Walsh, 2003; Orlitzky, Schmidt and Rynes, 2003; Hillman and Keim, 2001; McWilliams and Siegel, 2000). However, a more recent study finds that differentiating among sustainability issues based on SASB's designated materiality of each issue yields much clearer results (Khan, et al., 2016). Firms with good ratings on material sustainability issues significantly outperform firms with poor ratings on these issues. In contrast, firms with good ratings on immaterial sustainability issues do not significantly outperform firms with poor ratings on the same issues. These results are confirmed when analyzing future changes in accounting performance. In this paper, we follow the materiality analysis and methodology in Khan et al. (2016), and extend their procedure by classifying shareholder proposals that address ESG issues as financially material or immaterial. We also extend their procedure by mapping material issues for all of the ten SASB sectors and nearly 80 eighty industries.

\section{Shareholder Activism on Sustainability Issues}


Several papers have analyzed investor activism on ESG issues. One study analyzed shareholder proposals regarding human rights and labor standard issues and found that proposals submitted between 1970 and 2003 asked for the adoption of codes of conduct rather than changes in practice in specific regions (Proffitt and Spicer, 2006). Moreover, the same study found that half of the proposals were sponsored or co-sponsored by religious groups with the second most frequent sponsor being public pension funds. Religious groups as the major drivers of ESG activism was later confirmed by another study that analyzed proposals to 81 US companies between 2000-2003 (Monks et al., 2004). Another early study analyzed shareholder activism on social and environmental issues and found that they became increasingly frequent between 1970 and 1982 and that this increased frequency related to political and ideological processes and sentiments (Vogel, 1983). Overall, many of these early descriptive studies found that average support for ESG proposals was low and ranged between 6 and 8 percent (Campbell et al., 1999; Monks et al., 2004; Tkac, 2006).

The results on the effect of this activism are mixed. One study concluded that shareholder proposals on environmental issues had a negligible or even negative effect on firms' environmental performance (Clark et al., 2006). The same conclusion was reached by another study that investigated the effect of environmental and social proposals on firms' environmental and social performance (David et al., 2007). The authors justified this effect by arguing that companies spend resources to resist the proposals taking resources away from improving their sustainability performance and that any changes that management agrees to make are symbolic rather than substantive. Similarly, a study of social activism by the public pension fund CalPERS failed to find any effect on shareholder value after the activism (Barber, 2006). 
More recent research provides some evidence that investor activism on ESG issues affects corporate behavior and/or shareholder value. One study found that shareholder proposals on ESG reporting issues lead to increases in transparency on ESG issues and the practice of more integrated reporting (Serafeim, 2015). ${ }^{7}$ Another study analyzed 2,152 engagements from a large asset manager and found that 382 of them were designated as successful (i.e. achieving the objective of the engagement) by the asset manager (Dimson, Karakas and Li, 2015). For the subset of successful engagements, the authors found significant increases in stock price and operating performance, consistent with such engagements improving the financial performance of the company. Another recent study examined a small number of ESG proposals that received majority support, which represented less than one percent of all proposals, and compared the stock price reactions around the passage of the proposals with those of proposals that failed by a small margin to receive majority support (Flammer, 2015). The stock returns were significantly positive for close call passage proposals and the study concluded that these ESG proposals were value enhancing.

\section{Materiality of Sustainability Issues and Shareholder Activism}

The number of sustainability issues a single firm can potentially invest in is very large. MSCI KLD, a leading data provider, ranks firms' performance on more than fifty distinct sustainability issues. ${ }^{8}$ An increasing number of managers recognize that a given sustainability issue is unlikely to be equally material for firms across industries. For example, managing climate change risk may be strategically important for some firms, while employee health and safety issues are more likely to be strategically important for other firms. Activism in the area of ESG issues has not

\footnotetext{
7 "An integrated report is a concise communication about how an organization's strategy, governance, performance and prospects, in the context of its external environment, lead to the creation of value in the short, medium and long term." See http://integratedreporting.org/what-the-tool-for-better-reporting/

${ }^{8}$ For more information see the dataset list at https://goo.gl/qugXSI.
} 
been driven traditionally by an assessment of materiality, though. Activism has primarily been driven by an approach where investors choose one topic, such as climate change or diversity, and then engage with a wide range of companies across industries (i.e. campaign) based on financial holdings, performance on the focal issue by the target companies, and/or the size of the target companies (Blackrock and Ceres, 2015). For example, an investor could target many large companies with poor performance on diversity issues, as part of the diversity campaign. Therefore, because a given issue can be immaterial for one industry and material for another (see Appendix III), one would expect that some of the proposals will be submitted on material and some on immaterial issues, where the exact percentage falling in either category being ex ante unclear. Based on interviews with the senior leadership of twelve of the most frequent sponsors in our dataset we learned that other reasons for investors submitting proposals on immaterial sustainability issues include the objective function of the engagement team not being strictly financial but pursuing other objectives, along with an imperfect and incomplete understanding of what is material in each industry. ${ }^{9}$

\section{Implications for ESG Performance}

Given the early literature that shows the ineffectiveness of investor activism on ESG issues and that proposals on ESG topics almost never receive majority support, one might expect no change in firms' ESG performance following engagement. However, the literature on social activism and organizational change provides a theory on why changes in organizational practices might be observed in this setting (den Hond and de Bakker, 2007). Social activists can elicit organizational change by challenging company actions' legitimacy on the basis of moral principles or pragmatic

\footnotetext{
${ }^{9}$ For example, the CEO of a prominent responsible investing asset management firm that we interviewed discussed how the head of the engagement efforts, who had a human rights background, was placing emphasis on human rights issues in submitting shareholder proposals without applying an investment lens on whether, how and under what conditions human rights could affect the financial performance of a company.
} 
concerns, such as "a business case for sustainability." Ferraro and Beunza (2014) conducted a qualitative study following a religious organization that filed shareholder proposals on a number of ESG issues for three years, and found that the investor used both financial and moral arguments to persuade corporate management and were sometimes successful. Firms presented with these challenges are motivated to take the activist group seriously, and reexamine the premise and content of the challenged frames in terms of the new arguments presented by the activists (Greenwood, Suddaby, and Hinings, 2002). Firms sufficiently threatened by the challenge are likely to generate new frames more consistent with the views espoused by the activists, which as a result change the set of organizational practices and beliefs these firms perceive as legitimate (den Hond and de Bakker, 2007; Lounsbury et al., 2003). A study that examined 94 shareholder proposals on environmental issues found an increased propensity of firms adopting the requests of the sponsor organization (Reid and Toffel, 2009).

To the extent that the null hypothesis of no change in ESG performance is rejected, one might expect larger increases in ESG performance following proposals on immaterial issues. This is because immaterial sustainability issues tend to be easier to address and they do not involve fundamental changes in the business model, processes and products of a company. In most cases they are under the direct supervision of a CSR manager or a Chief Sustainability Officer, who has the capacity to address such an issue in a short period of time, and has the responsibility and authority to invest resources without company-wide coordination and involvement (Miller and Serafeim, 2014). In contrast, material sustainability issues frequently require large investments, long-time horizons and fundamental changes in products, processes and business models that will affect multiple corporate functions (Eccles and Serafeim 2013; Miller and Serafeim, 2014). Addressing immaterial sustainability issues might be easier and 
requires spending relatively fewer resources, whereas addressing material sustainability issues requires structural changes in terms of how the firm makes money. This distinction coupled with the finding in previous studies that companies tend to resist shareholder proposals, leads to a prediction that proposals on immaterial issues might be more effective at increasing the performance of the company on the focal issue.

On the other hand, ESG performance might improve more on material issues if companies ignore proposals on immaterial issues, since such issues are not connected to a company's business model and strategy. Under the assumptions that managers have complete and perfect knowledge of the materiality of ESG issues and no agency problems exist between managers and shareholders, one would expect managers to improve ESG performance to a greater degree following shareholder proposals on material issues.

\section{Implications for Market Valuation}

If proposals have a negligible effect on a company's ESG performance then one might expect no effect on the firm's market valuation. In contrast, if the proposals lead to a change in a firm's ESG performance then this could affect the market valuation of a firm. Past research has shown that firms with good performance on material sustainability issues outperform firms with poor performance on those same issues (Khan et al., 2016). In contrast, firms' performance on immaterial issues is not predictive of future financial performance. One might then predict that after engagement on material sustainability issues, the market value of the company would increase while after engagement on immaterial issues, the market value of the company would be unaffected.

There are, however, a number of reasons why these predictions might not hold in the setting of activist-driven changes in corporate behavior relating to ESG. For instance, in the case 
of material sustainability issues, it is not clear whether investors pressure firms to improve their performance beyond the point that is optimal. Improving ESG performance in a way that is neutral to or synergistically improves financial performance is difficult. Quite often, companies find that critical trade-offs are involved, at least in the short term. At a certain point, higher ESG performance could come at a cost to shareholders (Eccles, Ioannou and Serafeim, 2014). This suggests that there could be an optimal degree of adoption of such practices, beyond which point a commitment to it becomes value-destroying, at least in the short term (Eccles, et al. 2014). While firms might be improving their performance on an ESG issue in a way and pace that make financial sense, this might not be true when they are faced with investor pressure. For example, moving towards renewable energy and achieving a target supply of 20 percent in ten years might be accomplished in a financially beneficial manner while the same target within three years might be accomplished by sacrificing financial returns and adopting technologies that might be less commercially advantaged.

Similarly, in the case of immaterial sustainability issues, firms might be forced to improve their performance and spend more resources than they would otherwise make in the absence of investor pressure. To the extent that this is true, then one might expect investments in immaterial sustainability issues being value decreasing, rather than value neutral, as was found in Khan et al. (2016). These proposals could be even more value destroying if they divert the attention of senior management and directors away from the most pressing business issues, leading to loss of customers and decreased competitiveness (Simons, 2013). Overall, the value implications from investor induced changes in ESG performance may be fundamentally different from the value implications of changes in ESG performance initiated by management. 


\section{DATA AND SAMPLE}

\section{Materiality Data}

Our data collection is driven by the availability of materiality guidance from SASB, which is an independent 501(c)3 non-profit whose mission is to develop and disseminate sustainability accounting standards that help publicly-listed corporations disclose material factors in compliance with SEC requirements. SASB standards are designed for the disclosure of material sustainability issues in mandatory SEC filings, such as the Form 10-K and 20-F. SASB is accredited to establish sustainability accounting standards by the American National Standards Institute (ANSI), and such accreditation is intended to signify that SASB's procedures to develop sustainability accounting standards meet the Institute's requirements for openness, balance, consensus and due process. SASB's board comprises a mix of regulators, academics, lawyers, and investors, including two former Chairwomen of the SEC and a former Chairman of the FASB.

SASB adopts an investor viewpoint and, as a result, a topic might be classified as immaterial from an investor standpoint although such a topic could be important for other stakeholders. That being said, we expect that there will be overlap between materiality classifications for different stakeholders if sustainability investments affect financial performance via their effect on, for example, customer satisfaction, loyalty, employee engagement, and regulatory risk. SASB uses the SEC definition of materiality as interpreted by the U.S. Supreme Court. ${ }^{10,11}$ The Public Company Accounting Oversight Board (PCAOB) also

\footnotetext{
${ }^{10}$ TSC Industries v. Northway, Inc., 426 U.S. 438, 449 (1976). See also Basic, Inc. v. Levinson, 485 U.S. 224 (1988).

${ }^{11}$ The Public Company Accounting Oversight Board is a nonprofit corporation established by the U.S. Congress to oversee the audits of public companies in order to protect investors and the public interest by promoting informative, accurate, and independent audit reports. http://pcaobus.org/About/Pages/default.aspx.
} 
refers to the U.S. Supreme Court ${ }^{12}$ interpretation of securities laws in its materiality guidance, that is, material information is defined as presenting a substantial likelihood that the disclosure of the omitted fact would have been viewed by the reasonable investor as having significantly altered the total mix of information made available. Like the PCAOB, SASB defines material information as information that represents a substantial likelihood that its disclosure will be viewed by the reasonable investor as significantly altering the total mix of information made available.

The investor focus of SASB is narrower compared to other organizations such as the Global Reporting Initiative (GRI), which has a multi-stakeholder focus. The GRI states that the information in a GRI-compliant report should cover Aspects ${ }^{13}$ that: reflect the organization's significant economic, environmental, and social impacts; or substantively influence the assessments and decisions of stakeholders. Materiality for the GRI is the threshold at which Aspects become sufficiently important that they should be reported. ${ }^{14}$

SASB's standards are developed via a multi-stakeholder process consisting of research supported by Bloomberg technology, data and analytical tools; balanced, multi-stakeholder industry working groups; a public comment period; and review by an independent Standards Council comprised of experts in standards development, securities law, environmental law, metrics and accounting. ${ }^{15}$ Appendix I illustrates each step of the standard setting process. SASB

\footnotetext{
${ }^{12}$ TSC Industries v. Northway, Inc., 426 U.S. 438, 449 (1976). See also Basic, Inc. v. Levinson, 485 U.S. 224 (1988).

${ }^{13}$ The term "Aspect" is used in the GRI G4 Guidelines (Guidelines) to refer to the list of subjects for disclosure that are covered by the Guidelines. Aspects are set out into three Categories - Economic, Environmental and Social. The Social Category is further divided into four sub-Categories, which are Labor Practices and Decent Work, Human Rights, Society and Product Responsibility. See https://www.globalreporting.org/resourcelibrary/GRIG4-Part1Reporting-Principles-and-Standard-Disclosures.pdf.

${ }^{14}$ Global Reporting Initiative. G4 Sustainability Reporting Guidelines, Reporting Principles and Standard Disclosures, https://www.globalreporting.org/resourcelibrary/GRIG4-Part1-Reporting-Principles-and-StandardDisclosures.pdf.

${ }^{\frac{15}{15} \text { See www.sasb.org }}$
} 
convenes balanced industry working groups-consisting of $1 / 3$ corporations, 1/3 market participants, and 1/3 other stakeholders - to provide feedback on SASB's draft sustainability accounting standards. More than 3,000 experts representing more than $\$ 30$ trillion in assets under management and \$15 trillion in company market capitalization had participated in SASB's industry working groups between 2013 and 2016.

For each topic, SASB conducts an evidence of materiality test, informed by staff research and industry working groups, the results of which ultimately are debated and reviewed by the Standards Council after industry working groups composed of industry experts have provided their input. The test has three components: evidence of interest, evidence of financial impact, and forward impact adjustment. We describe each one in more detail in Appendix II but the interested reader can find more information on the SASB website.

\section{Sustainability Data}

We use MSCI KLD as our source of sustainability data, the most widely used dataset in past studies. For the purposes of this paper, KLD has a number of advantages. First, it includes a large number of U.S. companies over a long period of time. In particular, between 1991 and 2000 it included approximately 650 companies, 2001-2002 1,100 companies, and 2003-2012 3,000 companies. Other databases with sustainability data (for example, Thomson Reuters ASSET4) have shorter time-series and cover fewer U.S. companies. Another advantage of the KLD data is that it provides information about performance on a specific issue in a standardized format rather than the presence or absence of disclosure, as is the case for many data items in ASSET4 or Bloomberg.

KLD data have been widely used in the literature by researchers examining the relation between social responsibility and financial performance (e.g., Graves and Waddock, 1994; 
Turban and Greening, 1997; Mattingly and Berman, 2006; Godfrey, Merrill, and Hansen, 2009; Ioannou and Serafeim, 2014). Researchers at KLD review the company's public documents, including the annual report, the company website, corporate social responsibility reporting, and other stakeholders' and data sources. Company ratings represent a snapshot of the firm's profile at calendar year end. KLD researchers also monitor media sources for developing issues on a daily basis. The KLD dataset is compiled around the beginning of every year (i.e. January) and it is typically available in spreadsheets for distribution by end of February at the latest.

The KLD historical ratings data set is designed as a binary system and comprises both strengths and concerns. Strengths represent policies, procedures, and outcomes that enable a firm to have a positive impact on the focal issue. Concerns represent policies, procedures, and outcomes that tend to have a negative impact on the focal issue. For each strength or concern rating applied to a company, KLD includes a "1" indicating the presence of that screen/criterion and a "0" indicating its absence. In total, seven issue areas are included: a) Community, b) Corporate Governance, c) Diversity, d) Employee Relations, e) Product, f) Environment, and g) Human Rights. Within each issue area, multiple topics and respective data items exist. For example, under the Environment issue area, KLD tracks performance on waste management, packaging materials and waste, environmental opportunities, climate change, and water stress, among other issues. Under the Social issues area, KLD tracks performance on community engagement, human rights, union relations, workforce diversity, and access to finance, among other issues. Under Governance issues area, KLD tracks performance on issues including reporting quality, corruption and political instability, financial system instability, governance structure, and business ethics. 
Table 1 shows how we arrive at the final sample from the original ISS dataset from years between 1997 and 2012. We do not include years 2013 and 2014 because MSCI has made significant changes to KLD indicator classification since the 2013 data. Starting from 4,796 SRI proposals, we remove omitted proposals, sustainability reporting related resolutions and observations with missing data to arrive at the final sample of 2,665 proposals. We exclude sustainability reporting proposals because they are a request to increase transparency across a range of ESG issues and therefore we cannot classify them as material or immaterial. Table 2 shows the number of total proposals and the proportion of material proposals by year, sector, and sponsor type. Panel A shows that the percentage of material proposals range from 29 to 52 percent during the years 1997 to 2012 . On average, 42 percent of the proposals were on material issues. Panel B shows the distribution of proposals across sectors. Forty-nine percent of the proposals were material for the energy, 42 for the materials, 32 for the industrials, 44 for the consumer discretionary, 46 for the consumer staples, 26 for the healthcare, 55 for the financials, 32 for the information technology, 45 for the telecommunication services, and 42 for the utilities sector, respectively. Panel C shows the sample by sponsor type. The sample comprises of 240 proposals from individuals, 466 from public pension funds, 663 from religious groups, 604 from SRI funds, 250 from special interest groups, 195 from union funds, and 224 from coalitions. Firms are allocated to sectors and industries according to the Bloomberg Industrial Classification System (BICS) and the Sustainability Industrial Classification System (SICS). ${ }^{16}$ We mapped every industry in BICS to every industry in SICS in order to merge financial data with

\footnotetext{
${ }^{16}$ For more information see http://www.sasb.org/sics/
} 
sustainability data. BICS is the standard system used by investments banks and money management firms. ${ }^{17}$

\section{Identification of the Materiality and Immateriality Proposals}

In order to classify ISS proposals as material or immaterial, we first attach KLD data items to each unique proposal in our data, using the 'resolution' data field from ISS which contains a oneline description of the proposal. Then, we follow guidance from SASB for each one of the more than 80 SICS industries in our sample to classify each KLD data item as material or immaterial. Specifically, we download each industry standard that identifies material sustainability issues for companies within an industry. To identify KLD topics to ISS proposals and classify the topics' materiality, one researcher takes the lead in one sector and all the industries included in that sector. For each industry, KLD data items that are mapped to material SASB items are classified as material for a given industry, and all remaining KLD items are classified immaterial for the same industry. After having a complete mapping, another researcher follows the same process. The two mappings are then compared by a third researcher, who assesses any differences. In our case, differences in mappings across researchers were minimal. ${ }^{18}$

Appendix III shows the materiality map of SASB at the sector level and Appendix IV presents two examples of shareholder proposals and how they were coded. A more granular view at the industry level can be obtained by visiting the SASB website. Industries within a sector generally had similar issues classified as material but differences could be found. Approximately 50 percent of all possible sector-SASB issue pairs were either material or immaterial for all industries within the sector. The largest variability across industries within a sector is in the

\footnotetext{
${ }^{17}$ SASB's industrial classification system is powered by the Bloomberg Industry Classification System. SASB leverages the Bloomberg Industry Classification System to identify which industry companies are assigned to.

${ }^{18}$ The two researchers disagreed on $1 \%$ of the total number of mappings. These differences were resolved by consultation with the third researcher.
} 
services sector where only 20 percent of the issues were either material or immaterial across all industries. The lowest variability is within the financials and technology and communication sectors with more than 67 percent. The total number of material items identified is small compared to the total number of KLD data items, which is 124 , consistent with SASB claims that their guidance narrows significantly the number of issues that a firm needs to disclose. The number of material data items ranges from 13 for the healthcare sector to 32 for services sector while the financials, transportation, and the nonrenewable resources sector have 22, infrastructure has 25 , consumption 1 has 21 , consumption 2 has 31 , resource transformation has 20, and the technology and communications sector has 19 data items that are material. Broadly speaking, environmental issues tend to be more material for the nonrenewable resources and transportation sectors, governance and product related issues tend to be more material for the financial sector, and social issues tend to be more material for the healthcare, services, and the technology and communications sectors. Appendix III provides more detailed information, and for industry mappings the interested reader can visit the SASB website.

To construct an index that measures a firm's performance on a KLD category topic $j$ that a shareholder proposal relates to (i.e. diversity, employee relations, product safety, environment etc.) for firm $i$ in year $t$, we follow the practice, common in prior literature, of subtracting the concerns from the strengths to arrive at a single net index (e.g., Graves and Waddock, 1994; Griffin and Mahon, 1997; Waddock and Graves, 1997; Johnson and Greening, 1999; Ruf et al., 2001; Ioannou and Serafeim, 2014):

Category Index $_{i j t} \quad=\sum S T R E N G T H_{i j t}-\sum C O N C E R N_{i j t}$

Table $3 \mathrm{a}$ and Table $3 \mathrm{~b}$ presents summary statistics and univariate correlations between the variables used in our analysis. We adjust both category index and Tobin's Q for each firm- 
year using the median level within industry. The average value of the industry-adjusted category index is negative suggesting that investors target firms with relatively weak performance on the focal ESG issue. The average industry-adjusted Tobin's Q is positive consistent with the firms being targeted in our sample being large and profitable firms.

It is worth noting that if a shareholder proposal on one firm motivates action in other firms in the same industry and same topic (e.g. filing a water related proposal for Pepsico leads to Coca Cola taking action on water related issues), then adjusting for the median level of the industry effectively biases the coefficients towards zero and against finding any results. Therefore, our research design could be a conservative test of the effectiveness of shareholder proposals in the presence of industry spillover effects.

\section{Research Design}

We construct a panel dataset that consists of 26,423 firm-year-proposals and use the following specification as a base to conduct our analyses. We include five years before the year of the proposal and five years after the year of the proposal in addition to the year of the proposal in our sample. Our research design is similar to the one used by studies that test for the long-term effect of hedge fund activism (e.g. Bebchuk, et al., 2015):

Dep $\operatorname{Var}_{i j t}=\alpha+\beta^{*} \sum_{t}$ Event Time Indicator $_{i j t}+\gamma^{*} \sum_{t}$ Material $_{i t} X$ Event Time Indicator $_{i j t}+$ Controls $_{i t}+$ year f.e.+ firm-proposal f.e.

The dependent variables are Category Index and Tobin's Q, both of which are adjusted by the industry median. ${ }^{19}$ Adjusting for industry median effectively controls for time-varying changes in industry ESG performance and market valuation.

\footnotetext{
${ }^{19}$ We use GICS industries as the level of industry adjustment. Adjusting at the sub-industry or at the sector level yields similar results. We include all firms with available data in Compustat as the sample for calculating the median value for each industry-year.
} 
Tobin's Q, named after Noble-prize-winner James Tobin, is "a measure that reflects the effectiveness with which a company turns a given book value into market value accrued to investors" (Bebchuk, et al., 2015). Tobin's Q has been used extensively in studies that seek to measure the efficiency of corporate practices or institutions, such as governance arrangements, ownership structures, or investor protection rules (Morck, Shleifer and Vishny, 1988; Bebchuk, et al., 2015). Event-time indicators are $\mathrm{T}$ through $\mathrm{T}+5$, where $\mathrm{T}$ indicates the year that a sponsor submits a proposal, $\mathrm{T}+1$ indicates the year after a sponsor submitted a proposal, $\mathrm{T}+2$ indicates two years after a sponsor submitted a proposal, and etc. Material is an indicator variable equal to one if the shareholder proposal is material, zero otherwise. We interact Material and the series of Event Time Indicators to denote each year with respect to the base year with a material engagement. For example, Material $\mathrm{X} \mathrm{T}$ is an indicator equal to one for material proposals in the year of engagement, and zero for every year before and after the engagement; Material $\mathrm{X} T+1$ is an indicator equal to one for material proposals one year after the engagement and zero for every year before and after $\mathrm{T}+1$; and Material $\mathrm{X} \mathrm{T}+2$ is an indicator equal to one for material proposals two years after the engagement and zero for every year before and after $\mathrm{T}+2$, and so on.

We include a series of firm-level time-varying controls that are identified to be correlated with firm value and firm ESG performance in the prior literature. Log of Assets is defined as the natural logarithm of total assets. Capex/Assets is defined as the ratio of capital expenditure and total assets and $\mathrm{R} \& \mathrm{D} /$ Assets is defined as the ratio of research and development expense and total assets. Leverage is defined as the sum of long-term debt and current debt divided by total assets. Governance proposal is a dummy variable equal to one if any of the ESG proposals were accompanied by a corporate governance proposal in each of the years, and subsequent years, that a given firm was engaged on a traditional governance topic (i.e. executive compensation, anti- 
takeover provision, etc.), and zero otherwise. We also include year fixed effects to mitigate the effect of any year-specific and firm invariant omitted variables, and firm-proposal fixed effects to mitigate the effect of any firm-proposal specific but time invariant omitted variables (e.g. Rio Tinto and community relations versus Rio Tinto and water consumption). The inclusion of firmproposal fixed effects and year fixed effects automatically subsumes heterogeneity at the firm, proposal and time period levels, such that our identification relies on variation within the same proposal for the same firm, over time.

\section{Unobservable Factors and Selection Bias}

First, we note that adjusting for industry median potentially downward biases the coefficients of interest if some of the industry members are also experiencing shareholder activism that we do not observe (i.e. private engagement). If these private engagements lead to changes in firms'

ESG and financial performance in the same way that public engagements do, then our tests will fail to find any effect from shareholder activism. Second, a phenomenon that might bias against finding an effect from shareholder activism is if the firm that the sponsor files a proposal for has been improving its ESG performance before the year of the shareholder proposal through private engagements with investors. In this case, our coefficients of interest will be biased towards zero as they effectively model performance relative to the period prior to the year in which the shareholder proposal is filed. In contrast, if engaged firms were making changes without shareholder activism and following the shareholder proposal these management-initiated changes are generating performance differences, this will lead us to incorrectly reject the null hypothesis of no effect although the changes in observed ESG performance and firm valuation are not the result of shareholder activism. 
It is nearly impossible to completely mitigate the first effect. Therefore, readers should interpret our results as potentially providing a lower bound of the effectiveness of shareholder proposals. To the extent that private engagements are happening at the same rate and have similar effectiveness across material and immaterial issues, this will not affect the implications from shareholder proposals filed on material or immaterial issues. However, if private engagements are more focused on and are more effective for immaterial issues, then we would find a stronger effect on ESG performance from proposals filed on material issues. Similarly, if private engagements are more focused on and are more effective for material issues, then we would find a stronger effect on ESG performance from proposals filed on immaterial issues.

The second and third effect suggests that there could be a pre-shareholder proposal trend in ESG performance. We formally test for this possibility by plotting in Figures $1 \mathrm{a}$ and $1 \mathrm{~b}$ the evolution over time of our dependent variables: industry-adjusted category index and Tobin's Q. We find that for the five years prior to engagement, industry-adjusted category index is flat for immaterial issues and declining for material issues suggesting that, at least for material issues, investors engage with firm with deteriorating material ESG performance. Across both material and immaterial engagements, firms have negative industry-adjusted category index suggesting that investors target firms with poor ESG performance. For both material and immaterial issues, Tobin's Q is declining over time suggesting that investors engage with firms with declining financial performance. However, we do note that the industry-adjusted Tobin's Q is positive suggesting that these are profitable firms relative to their industry peers. We note these trends as they might affect inferences drawn in our main results.

To address concerns that pre-shareholder proposal trends might affect subsequent trends in category index or Tobin's Q, we implement a nearest-neighbor propensity score matching 
process with replacement. We use exact matching for the year of the engagement from a pool of firms that have not been subject to engagement. Then we propensity score match using the following model:

Engagement $_{i t}=f\left(\right.$ Firm size $_{i t-1}$, Tobin's $Q_{i t-1}$, Tobin's $Q_{i t-2}$, Tobin's $Q_{i t-3}$, Tobin's $Q_{i t-4}$, Tobin's $Q_{i t-5}$, Category Index $x_{i j t-1}$, Category Index $x_{i j t-2}$, Category Index $x_{i j t-3}$, Category Index $x_{i j t-4}$, Category

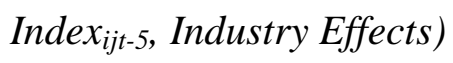

Effectively, model (3) matches 'treatment' firms that experienced activism to 'control' firms that did not experience activism and have very similar levels of both Tobin's Q and Category Index for the five years before the activism. Therefore, both the levels and the trends should be very similar across the two groups. We then estimate model (2) but instead of industry-adjusting the outcome variable (i.e. Category Index or Tobin's Q), we adjust for the level of the matched control firm. Out of the 2,665 proposals we find a suitable match for 2,336 (88\%). This leaves us with 22,246 firm-year-proposal observations for the matched sample. Figures $2 \mathrm{a}$ and $2 \mathrm{~b}$ show no differential trends over time for the matched sample relative to the control sample suggesting that the matching procedure worked effectively. This is the case both for material and immaterial proposals. Moreover, treatment and control firms exhibit very similar levels of category index and Tobin's Q across all years before the engagement. Table 4 presents the average values for all matching covariates for both treatment and control groups. None of the differences is statistically significant. The univariate correlation between the industry adjusted and the matched control adjusted category index (Tobin's Q) is $0.40(0.37)$.

\section{RESULTS}

\section{Sustainability Performance}


Table 5a presents evidence on the association between shareholder proposals and subsequent ESG performance. We implement a panel-level specification using industry-adjusted category index score as the dependent variable. Recall that this dependent variable measures the firm's performance, over time, on the focal ESG topic identified by the shareholder proposal. In Column 1, we regress the dependent variable on event-time indicators $(\mathrm{T}$ through $\mathrm{T}+5)$ where $\mathrm{T}$ is the year that a sponsor submits a proposal, interactions of event-time dummies with the "Material" indicator that takes the value of one if the proposal is on a material ESG issue, year fixed effects, and firm-proposal fixed effects. This basic specification enables us to understand the difference in impact between shareholder proposals filed on material and immaterial sustainability issues on firm ESG performance over time, controlling for firm- year- and proposal- invariant factors. In Column 2, we add firm size, capital expenditure, R\&D expense, and leverage to the original specification to control for time-varying firm financial characteristics that could affect a firm's ESG performance. In Column 3 we add an indicator for corporate governance proposals, which is equal to one if in any of the previous five years a governance proposal has been submitted for this firm. This is to prevent us from potentially attributing the increase in category index score to ESG engagements as opposed to governance engagements. In all three specifications, we find that proposals filed on immaterial issues are accompanied by larger and faster increases in a firm's performance on the ESG issue that the proposal identifies, relative to proposals on material issues. The coefficients on the interactions of event-time indicators with the Material indicator are negative but barely significant, suggesting that, statistically, proposals on material issues have no differential effect on ESG performance compared to proposals on immaterial issues. 
These results are confirmed in Table $5 \mathrm{~b}$ which uses the propensity score matched sample. The coefficients are similar and again we find sharper increases after activism on immaterial ESG issues. Similar to Table 5a, performance on the focal ESG issues increases after activism on material and immaterial issues. Figures $3 \mathrm{a}$ and $4 \mathrm{a}$ provide a graphical illustration that corroborates our panel results: engagement via shareholder proposals is associated with improved subsequent performance of the company on the focal ESG issue across both material and immaterial issues.

\section{Firm Value}

Table 6a presents evidence on the impact of shareholder proposals on firm value. Similar to Table 5a, we implement a panel-level specification. In Column 1, we regress industry-adjusted Tobins' $\mathrm{Q}$ on event-time dummies (T through $\mathrm{T}+5$ ), interactions of event-time indicators with the "Material" indicator, year fixed effects, and firm-proposal fixed effects. This enables us to understand the difference in impact between shareholder proposals filed on material and immaterial sustainability issues on firm value over time. In Column 2, we control for timevarying firm financial characteristics and in Column 3 we again include the corporate governance proposal indicator to prevent us from potentially attributing the increase in firm value to ESG engagements as opposed to governance engagements. In Column 4, we exclude observations of firms that experienced both a material and immaterial proposal within a same 2year span from column 3 to ensure that we are able to differentiate the effect of proposals relating to material versus immaterial topics. This is because in cases where both material and immaterial proposals were submitted around the same year for the same firm, our specification would not be able to differentiate between the effects of the different proposals on firm value. 
In all four specifications, we find that subsequent to filing shareholder proposals, targeted firms experience changes in Tobin's Q over time. However, proposals have a substantially different effect depending on whether they relate to immaterial versus material issues. Proposals on immaterial issues are associated with subsequent declines in Tobin's Q. In contrast, proposals on material issues are associated with subsequent and steady increases in Tobin's Q. These results are confirmed in Table $6 \mathrm{~b}$ using the propensity score matched sample. Figures $3 \mathrm{~b}$ and $4 \mathrm{~b}$ are a graphical illustration that corroborates our panel results: pressure on companies to address ESG issues that are not financially material for the firm but are relevant to other stakeholders is associated with subsequent declines in market valuation, while the opposite is true for proposals on material issues.

\section{Additional Analyses}

Why Do Firms Increase Performance on Immaterial Issues?

Our results suggest that firms increase their performance on immaterial issues following shareholder proposals on such issues and that their market valuation decreases subsequently. We consider and test potential reasons for why managers increase their organization's performance on immaterial issues. The first explanation that we consider is agency costs. Managers may not act in the best interests of shareholders but rather respond to engagement on immaterial proposals in order to satisfy the sponsoring shareholders and protect their reputations. We test this explanation by examining whether the increase in performance on immaterial issues is more pronounced for highly profitable firms, which may be prone to agency problems due to free cash flow (Jensen, 1986), and less pronounced for firms with less entrenched boards, which the literature suggests is a characteristic of better governance. We define an indicator variable for firms that have return-on-assets at the top quartile of their industry at the year of proposal. 
Similarly, we define an indicator variable taking the value of one for firms that score at the bottom quartile of the E-index constructed by Bebchuk, Cohen and Ferrell (2009). The results are presented in Panel A of Table 7 and are consistent with agency problems being part of the explanation for managers improving performance on immaterial issues. We find that the most profitable firms increase their performance on immaterial issues more than other firms, consistent with the agency costs of free cash flow. We also find that the firms that are most shareholder-friendly and that have the least entrenched boards increase their performance on immaterial issues significantly less.

Another explanation is that firms did not know which sustainability issues were financially material, and thus responded similarly to material and immaterial ESG proposals. Indeed past research has found that many firms lack the capabilities and stakeholder engagement practices that enable the identification of material issues (Eccles, Ioannou and Serafeim, 2014) even among firms that have relatively advanced management and reporting sustainability practices (Miller and Serafeim, 2015). If managers are uninformed about materiality, then we would expect firms that have good performance on both material and immaterial issues before the proposal to respond more to immaterial proposals compared to firms that had good performance on material issues but poor performance on immaterial issues. Khan et al., (2016) suggest that firms that invest only in material issues are likely to have concentrated their efforts only the material issues after undertaking a careful materiality analysis. In contrast, firms that performed well on all issues had failed to undertake a materiality analysis. In Panel B of Table 7, the coefficients on High on Immaterial \& High on Material X $T$ to $T+5$ shows supportive evidence that increases in performance on immaterial issues are partly driven by firms that do not know which issues are material. 
A third explanation that we consider is a hypothesis of "goodwashing." Under this explanation, firms might increase their performance on immaterial issues to divert attention away from poor performance on material issues. Recall that material issues require significantly more investment of time and resources on the part of the firm than immaterial issues. If firms are engaging in this behavior, then we would expect firms that had good performance on immaterial issues but bad performance on material issues before the proposal, to improve their performance on immaterial issues more than firms that had good performance on material but bad performance on immaterial issues. In Panel B of Table 7, the coefficients on High on Immaterial \& Low on Material X $T$ to $T+5$ shows supportive evidence that increases in performance on immaterial issues may be driven in part by firms that are trying to divert attention from their poor performance on material issues.

High versus Low ESG Performance

Table 8 presents additional tests on the impact of shareholder proposals on firm value and ESG performance. In the first two columns, we divide our sample into two groups based on the category index score at time $\mathrm{T}$, the year that the proposal was filed, to conduct cross sectional tests. We do this after excluding firms that experienced both a material and immaterial proposal within a same 2-year span. In Column 1, we take firms with an above-median category index score ('Category Index High') and regress the industry adjusted Tobin's Q on event-time dummies ( $\mathrm{T}$ through $\mathrm{T}+5)$, interactions of event-time indicator variables with the Material indicator, and all of the aforementioned controls and fixed effects. In Column 2, we take the firms with below-median category index score ('Category Index Low') and conduct the same regression. 
We find that the positive effect of proposals on material issues is present for both companies that start from low or high levels of performance on the focal sustainability issue. For the former, the increase in Tobin's Q is faster and plateaus soon after the engagement, suggesting that firms starting from a low level of performance respond by addressing issues that can create value immediately (e.g. implementing processes that reduce environmental inefficiencies, adopting practices to manage the workforce more productively and to ensure product quality and safety). For the latter, the increase in Tobin's Q is realized more gradually over time and continues up to five years after the engagement, suggesting that firms starting at a high level respond by maintaining a position of leadership on the focal ESG issue and differentiating themselves over time, thereby creating a competitive advantage in product, labor and/or capital markets (e.g. offering products that enable environmental protection, providing economicallydisadvantaged consumers with access to products, or becoming leaders by establishing a strong reputation for socially responsible procurement, production, and distribution). Figure III graphically illustrates this set of results.

\section{Voted Only Proposals}

Bauer et al. (2015) notes that ESG proposals are withdrawn relatively more often than corporate governance proposals, suggesting either an increased level of mutual understanding and/or specific action taken by the company, or symbolic actions taken to placate shareholders that ultimately do not result in ESG performance changes. As such, we replicate the main results of Table 5 and 6 by excluding withdrawn proposals from our sample in Table 7, Columns 3 and 4. When examining the difference in impact of shareholder proposals on immaterial and material ESG issues on firm value and firm ESG performance, our results remain virtually unchanged. This suggests that even within a set of proposals that are not withdrawn and subsequently receive 
relatively low levels of voting support, firms experience improvements in ESG performance and deteriorations (improvements) in market valuation after proposals on immaterial (material) sustainability issues. This is consistent with anecdotal evidence and industry practitioners suggesting that, even with low levels of voting support, ESG proposals often still prompt management to adopt some or all of the requested changes as a result of significant shareholder interest in the issues. ${ }^{20}$

\section{Recent Versus Early Proposals}

ESG disclosures and practices have increased dramatically over the past decade, as has demand from rating agencies, investors and other stakeholders for firms to measure and disclose their

ESG performance. ${ }^{21}$ As a result, we expect that firm responses to ESG proposals are greater in the latter period of our sample relative to the earlier period, due to managers becoming more aware of ESG issues and facing increased pressure to remedy concerns in more recent times. In untabulated results, we find evidence consistent with this hypothesis. Firms engaged on ESG issues from 1997 to 2004 only marginally increased ESG performance following engagement on immaterial issues but not material issues, whereas firms engaged on ESG issues from 2005 to 2012 significantly increased ESG performance in response to both immaterial and material proposals.

\section{CONCLUSION}

The number of shareholder proposals relating to sustainability issues has increased over the years, and comprised 40 percent of all proposals filed in 2013. In addition, the share of votes in favor of ESG proposals has nearly tripled from 8 percent in 1999 to 21 percent in 2013. Despite

\footnotetext{
${ }^{20}$ See http://www.ussif.org/resolutions

${ }^{21} \mathrm{See}$ https://www.globalreporting.org/resourcelibrary/Sustainability-and-Reporting-Trends-in-2025-1.pdf
} 
this increase in shareholder pressure relating to ESG issues, there is limited evidence as to whether shareholder activism relating to ESG improves sustainability performance, and whether firms benefit in terms of firm value. We fill this void by studying the ESG performance and firm value evolution following shareholder engagements relating to material and immaterial ESG issues. Using recent accounting standards innovations from the Sustainability Accounting Standards Board, which adopts the SEC's shareholder viewpoint in defining materiality and distinguishes between material and immaterial ESG issues by industry, we hand-map ESG resolutions in the ISS database from 1997-2012 to the recently-available industry-specific guidance on materiality from SASB. We find that 42 percent of shareholder proposals relating to sustainability topics are material, while the majority (58 percent) is immaterial. This suggests that a significant number of shareholders are unaware of materiality, or are pursuing objectives other than enhancing firm value.

Next, we track the targeted firms' performance on the ESG issue that was the focus of the proposal. Overall, we observe that filing shareholder proposals is effective at improving the performance of the company on the focal ESG issue across both material and immaterial issues. We find that proposals filed on immaterial ESG issues are accompanied by larger and faster increases in firms' performance on the ESG issue that the proposal identifies, relative to proposals on material issues. Firms appear to increase performance on immaterial issues post engagement for a number of reasons that include agency problems, a lack of understanding of which issues are material, and an attempt to divert attention from poor performance on material sustainability issues.

Moreover, we examine whether targeted firms experience changes in firm value subsequent to shareholder proposals on material and immaterial ESG issues. We document that 
proposals on immaterial issues are associated with subsequent declines in Tobin's Q. In contrast, proposals on material issues are associated with subsequent increases in Tobin's Q. This suggests that pressure on companies to address ESG issues that are not financially material for the firm but are relevant to other non-investor stakeholders could destroy financial value, while the opposite is true for proposals on material issues.

Our results suggest that failing to distinguish between material and immaterial sustainability issues might lead to erroneous conclusions. It is critical to make this distinction, because arguments made by influential policy experts that environmental and social issues are value-destroying, ${ }^{22}$ are supported only for a subset of the shareholder proposals in our sample; we find that a considerable portion (42 percent) of ESG proposals are financially material, and associated with subsequent increases in firm value.

${ }^{22}$ See http://www.bna.com/us-chamber-calls-n57982063976/ 


\section{REFERENCES}

Aupperle, K., Carroll, A. and Hatfield, J. 1985. An empirical examination of the relationship between corporate social responsibility and profitability. Academy of Management Journal 28.2: 446-463.

Barber, B. 2007. Monitoring the monitor: evaluating CalPERS activism. Journal of Investing, 16 (4): 66-80.

Barnett, M., and Salomon, R. 2006. Beyond dichotomy: The curvilinear relationship between social responsibility and financial performance. Strategic Management Journal 27.11: 1101-1122.

Bauer, R., Moers, F., and Viehs, M., 2015. Who Withdraws Shareholder Proposals and Does It Matter? An Analysis of Sponsor Identity and Pay Practices. Corporate Governance, 23: 472-488.

Bebchuk, L., Cohen, A. and Ferrell A.. 2009. What matters in corporate governance?. Review of Financial studies 22.2: 783-827.

Bebchuk, L., Brav, A. and Jiang W. 2015. The long-term effects of hedge fund activism. No. w21227. National Bureau of Economic Research.

Berman, S., Wicks, A., Suresh, K. and Jones, T. 1999. Does stakeholder orientation matter? The relationship between stakeholder management models and firm financial performance. Academy of Management Journal 42.5: 488-506.

Bizjak, J., and Marquette, C. 1998. Are shareholder proposals all bark and no bite? Evidence from shareholder resolutions to rescind poison pills. Journal of Financial and Quantitative Analysis 33.04: 499-521.

Black, B. 1998. Shareholder activism and corporate governance in the United States. As published in The New Palgrave Dictionary of Economics and the Law 3: 459-465.

BlackRock and Ceres, 2015. " $21{ }^{\text {st }}$ Century Engagement," Available at: http://www.ceres.org/press/press-releases/blackrock-ceres-launch-investor-guide-on-uscorporate-engagement

Borgers, A., Derwall, J. Koedijk, K. and ter Horst, J. 2013. Stakeholder relations and stock returns: On errors in investors' expectations and learning. Journal of Empirical Finance (22): 159-175.

Brammer, S., and Millington, A. 2008. Does it pay to be different? An analysis of the relationship between corporate social and financial performance. Strategic Management Journal 29 (12): 1325-1343.

Campbell CJ, Gillian, SL, and Niden CM. 1999. Current perspectives on shareholder proposals: lessons from the 1997 proxy season. Financial Management 28 (I): 89-98. 
Cheng, I., Hong, H. and Shue. K. 2014. Do Managers Do Good with Other People's Money?. No. w19432. National Bureau of Economic Research.

Clark G., Salo J., and Hebb T. 2006. Shareholder activism in the public spotlight: social investors' resolutions at US corporate annual meetings, 2001-2004. Pensions at work, University of Toronto.

Cochran, P., and Wood, R. 1984. "Corporate social responsibility and financial performance." Academy of Management Journal 27.1: 42-56.

David P., Bloom M. and Hillman A. 2007. Investor activism, managerial responsiveness and corporate social performance. Strategic Management Journal 28: 91-100.

Del Guercio, D. Cole, L. and Woidtke, T. 2008. Do Boards Pay Attention When Institutional Investor Activists 'Just Vote No'? Journal of Financial Economics (90): 84-103.

Di Giuli, A. and Kostovetsky, L., 2014, “Are red or blue companies more likely to go green? Politics and corporate social responsibility"., Journal of Financial Economic (111-1): 158-180.

Den Hond, F., and De Bakker F. 2007. "Ideologically motivated activism: How activist groups influence corporate social change activities." Academy of Management Review 32.3: 901924.

Dhaliwal, D, Radhakrishnan, S., Tsang, A., and Yang. Y. 2011. "Voluntary nonfinancial disclosure and the cost of equity capital: The initiation of corporate social responsibility reporting." The Accounting Review 86.1: 59-100.

Dhaliwal, D, Radhakrishnan, S., Tsang, A., and Yang. Y. 2012. "Nonfinancial disclosure and analyst forecast accuracy: International evidence on corporate social responsibility disclosure." The Accounting Review 87.3: 723-759.

Dimson, E., Karakaş, O. and Li, X. 2015 Active ownership. Review of Financial Studies 28.12: 3225-3268.

Eccles, R., and Serafeim. G. 2013. The Performance Frontier: Innovating for a Sustainable Strategy. Harvard Business Review 91, no. 5: 50-60.

Eccles, R., Ioannou, I. and Serafeim, G. 2014. The impact of corporate sustainability on organizational processes and performance. Management Science 60.11: 2835-2857.

Ertimur, Y., Ferri, F. and Stubben, S. 2010. Board of Directors' Responsiveness to Shareholders: Evidence from Shareholder Proposals. Journal of Corporate Finance 16, 53-72.

Ertimur, Y., Ferri, F. and Muslu, V. 2011. Shareholder activism and CEO pay. Review of Financial Studies: 113.

Ferraro, F., and Beunza, D. 2014. Understanding Voice: Mechanisms of Influence in Shareholder Engagement. Working Paper. 
Flammer, C. 2015. Does corporate social responsibility lead to superior financial performance? A regression discontinuity approach. Management Science 61.11: 2549-2568.

Fombrun, C. \& Shanley, M. 1990. What's in a name? Reputation building and corporate strategy. Academy of management Journal: 233-258.

Fombrun, C. 2006. Reputation. John Wiley \& Sons, Ltd.

Fombrun, C. 2005. A world of reputation research, analysis and thinking-building corporate reputation through CSR initiatives: evolving standards. Corporate Reputation Review 8.1: 7-12.

Freeman, R. E., Harrison, J. S., and Wicks, A. C. 2007. Managing for stakeholders: survival, reputation, and success. New Haven, CT: Yale Univ Press.

Freeman, R. 1984. Strategic Management: A stakeholder perspective. Boston, MA: Piman.

Friedman, M. 1970. The social responsibility of business is to increase its profits. New York Times Magazine, 32(13): 122-126.

Gillan, S. and Starks, L. 2000. Corporate Governance Proposals and Shareholder Activism: The Role of Institutional Investors. Journal of Financial Economics, 57, 2, 275-305.

Gillan, S. and Starks, L. 2007. The Evolution of Shareholder Activism in the United States. Journal of Applied Corporate Finance, 19: 55-73.

Godfrey, P. C., Merrill, C. B., and Hansen, J. M. 2009. The relationship between corporate social responsibility and shareholder value: an empirical test of the risk management hypothesis. Strategic Management Journal, 30(4): 425-445.

Graves, S. B. and Waddock, S. A. 1994. Institutional owners and corporate social performance. The Academy of Management Journal, 37(4): 1034-1046.

Greenwood, R., Suddaby, R., and Hinings, C. 2002. Theorizing change: The role of professional associations in the transformation of institutionalized fields. Academy of management journal 45.1: 58-80.

Guo R., T. Kruse and T. Nohel, 2008. Undoing the Powerful Anti-takeover Force of Staggered Boards. Journal of Corporate Finance 14, 274-288.

Hillman, A. J. and Keim, G. D. 2001. Shareholder value, stakeholder management, and social issues: what's the bottom line? Strategic Management Journal, 22(2): 125-139.

Hoi, C., Wu, Q. and Zhang, H. 2013. Is corporate social responsibility (CSR) associated with tax avoidance? Evidence from irresponsible CSR activities. The Accounting Review 88.6: 2025-2059.

Ioannis I., and Serafeim. G. 2012. What Drives Corporate Social Performance? The Role of Nation-Level Institutions. Journal of International Business Studies, 43: 834-864. 
Ioannou, I., and Serafeim, G. 2014. The consequences of mandatory corporate sustainability reporting: evidence from four countries. Harvard Business School working paper 11-100.

Jensen, M. C. 1986. Agency Costs of Free Cash Flow, Corporate Finance, and Takeovers. American Economic Review, 76(2): 323-329.

Jensen, M. C. 2002. Value maximization, stakeholder theory, and the corporate objective function. Business Ethics Quarterly, 12(2): 235-256.

Karpoff, J., 2001. The Impact of Shareholder Activism on Target Companies: A Survey of Empirical Findings, working paper.

Khan, M., Serafeim, G., and Yoon, A. 2016. Corporate sustainability: First evidence on materiality. The Accounting Review. Forthcoming.

Kim, Y., Park M. S., and Wier, B. 2012. Is earnings quality associated with corporate social responsibility?. The Accounting Review 87.3: 761-796.

Kotsantonis, S., Pinney, C. and Serafeim, G. 2016. ESG Integration in Investment Management: Myths and Realities. Journal of Applied Corporate Finance 28 (2): 10-16.

Lounsbury, M., Ventresca, M. and Hirsch, P. 2003. Social movements, field frames and industry emergence: a cultural-political perspective on US recycling. Socio-Economic Review 1.1: 71-104.

Margolis, J. D. and Walsh, J. P. 2003. Misery loves companies: rethinking social initiatives by business. Administrative Science Quarterly, 48(2): 268-305.

Mattingly, J., and Berman, S. 2006. Measurement of corporate social action discovering taxonomy in the Kinder Lydenburg Domini ratings data. Business \& Society 45.1: 20-46.

McWilliams, A. and Siegel, D. 1997. The Role of Money Managers in Assessing Corporate Social Reponsibility Research. The Journal of Investing, 6(4): 98-107.

McWilliams, A. and Siegel, D. 2000. Corporate social responsibility and financial performance: correlation or misspecification? Strategic Management Journal, 21(5): 603-609.

Miller, K. and Serafeim, G. 2014. Chief Sustainability Officers: Who Are They and What Do They Do? Chapter 8 in Leading Sustainable Change, Oxford University Press.

Monks, R., Miller, A., and Cook, J. 2004. Shareholder activism on environmental issues: A study of proposals at large US corporations (2000-2003). Natural Resources Forum. Vol. 28. No. 4. Blackwell Publishing Ltd.

Moser, D., and Martin, P. 2012. A broader perspective on corporate social responsibility research in accounting. The Accounting Review 87.3: 797-806.

Moskowitz, M. 1972. Choosing socially responsible stocks. Business and Society Review, 1(1): 71-75. 
Orlitzky, M., Schmidt, F. L., and Rynes, S. L. 2003. Corporate social and financial performance: A meta-analysis. Organization Studies, 24(3): 403-441.

Proffitt, W. Trexler, and Spicer, A. 2006. Shaping the shareholder activism agenda: Institutional investors and global social issues. Strategic Organization 4.2: 165-190.

Proxy Voting Analytics. 2014. Webpage: https://www.conferenceboard.org/publications/publicationdetail.cfm?publicationid=2857\&mkt_tok=3RkMMJWWfF9w sRomrfCcI63Em2iQPJWpsrB0B\%2FDC18kX3RUtJryYfkz6htBZF5s8TM3DU1BFXqdD\%2Bk EISLU\%3D

Reid, E., and Toffel, M. 2009. Responding to public and private politics: Corporate disclosure of climate change strategies. Strategic Management Journal 30.11: 1157-1178.

Serafeim, G., 2015. Integrated reporting and investor clientele. Journal of Applied Corporate Finance 27.2: 34-51.

Simons, R. 2013. "The business of business schools: restoring a focus on competing to win." Capitalism and Society 8.1.

Thomas, R. and F. Cotter. 2007. Shareholder Proposals in the New Millennium: Shareholder Support, Board Response and Market Reaction. Journal of Corporate Finance, 13, 368-391.

Tkac P. 2006. One proxy at a time: pursuing social change through shareholder proposals. Economic Review Third Quarter: 1-20.

Turban, D. B. and Greening, D. W. 1997. Corporate social performance and organizational attractiveness to prospective employees. The Academy of Management Journal, 40(3): 658-672.

Vogel D. 1983. Trends in shareholder activism: 1970-1982. California Management Review 25(3): 68-87.

Waddock, S., and Graves S. 1997. The corporate social performance-financial performance link. Strategic Management Journal 18.4: 303-319. 


\section{Figure 1a}

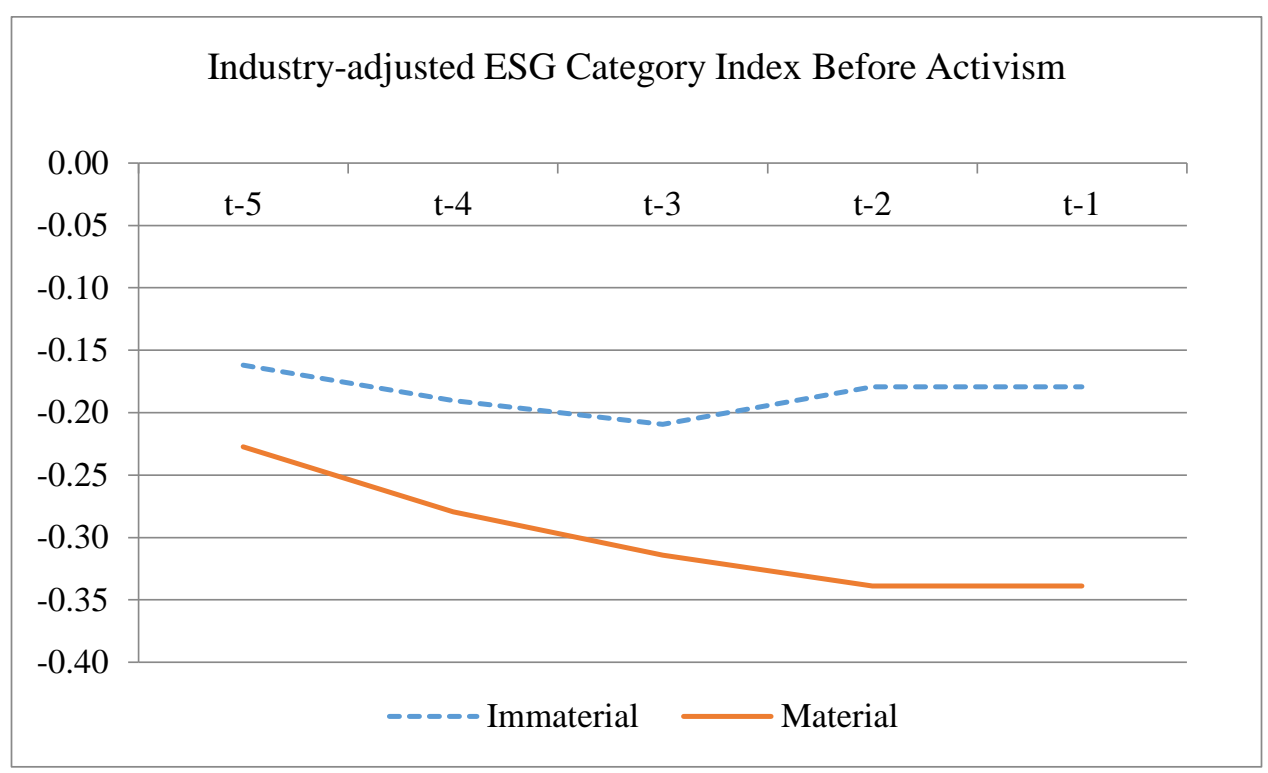

Figure 1b

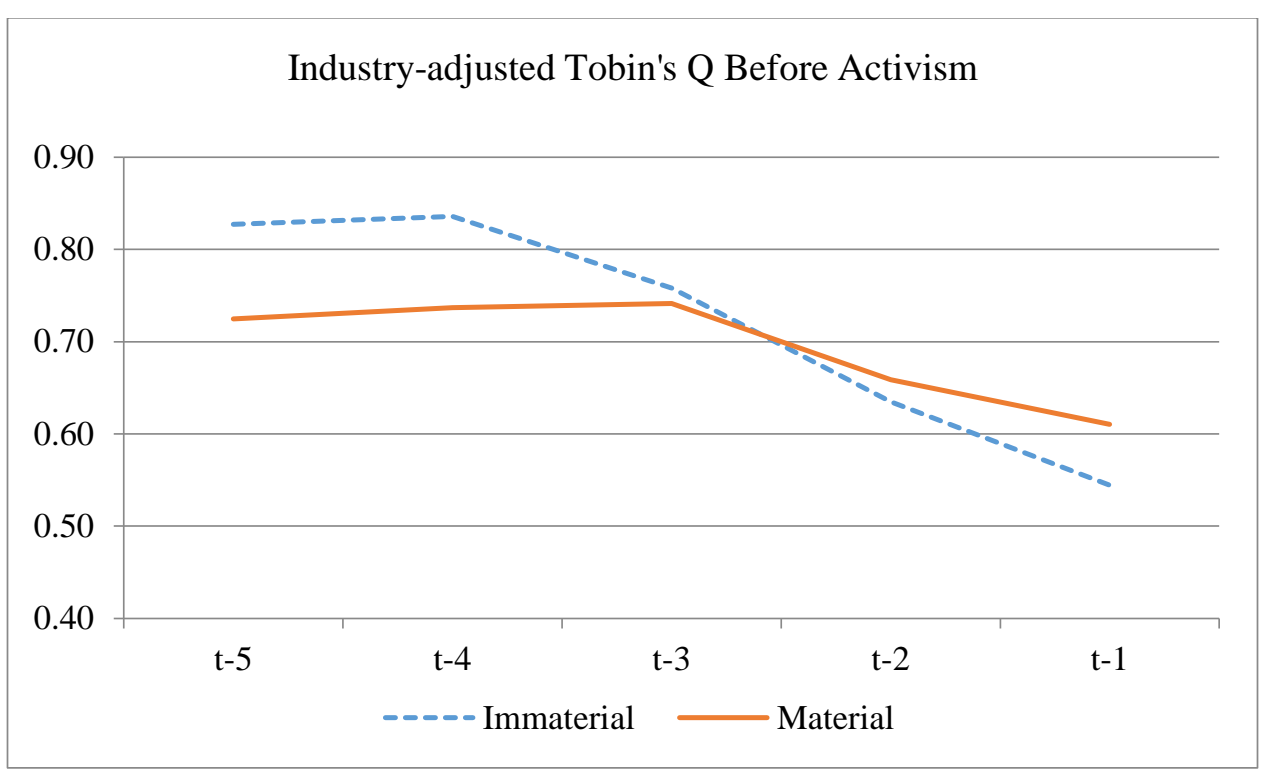




\section{Figure 2a}

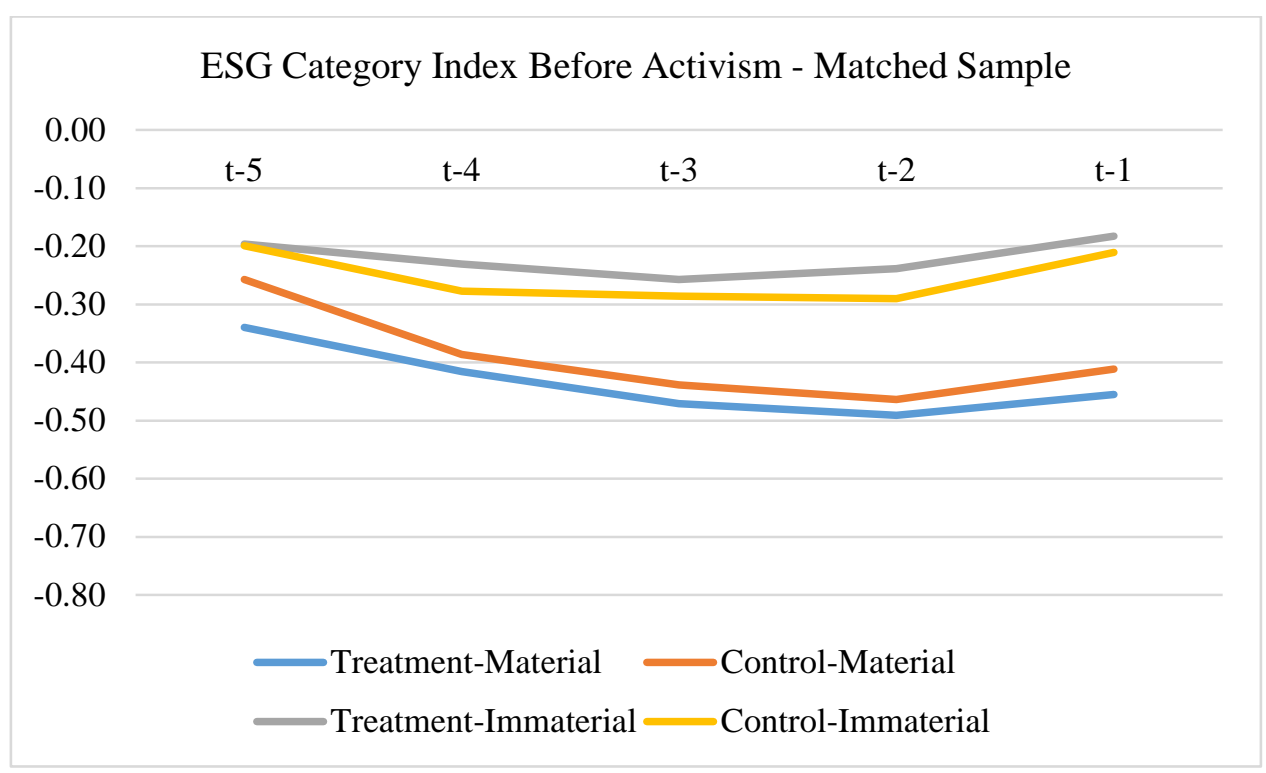

Figure 2b

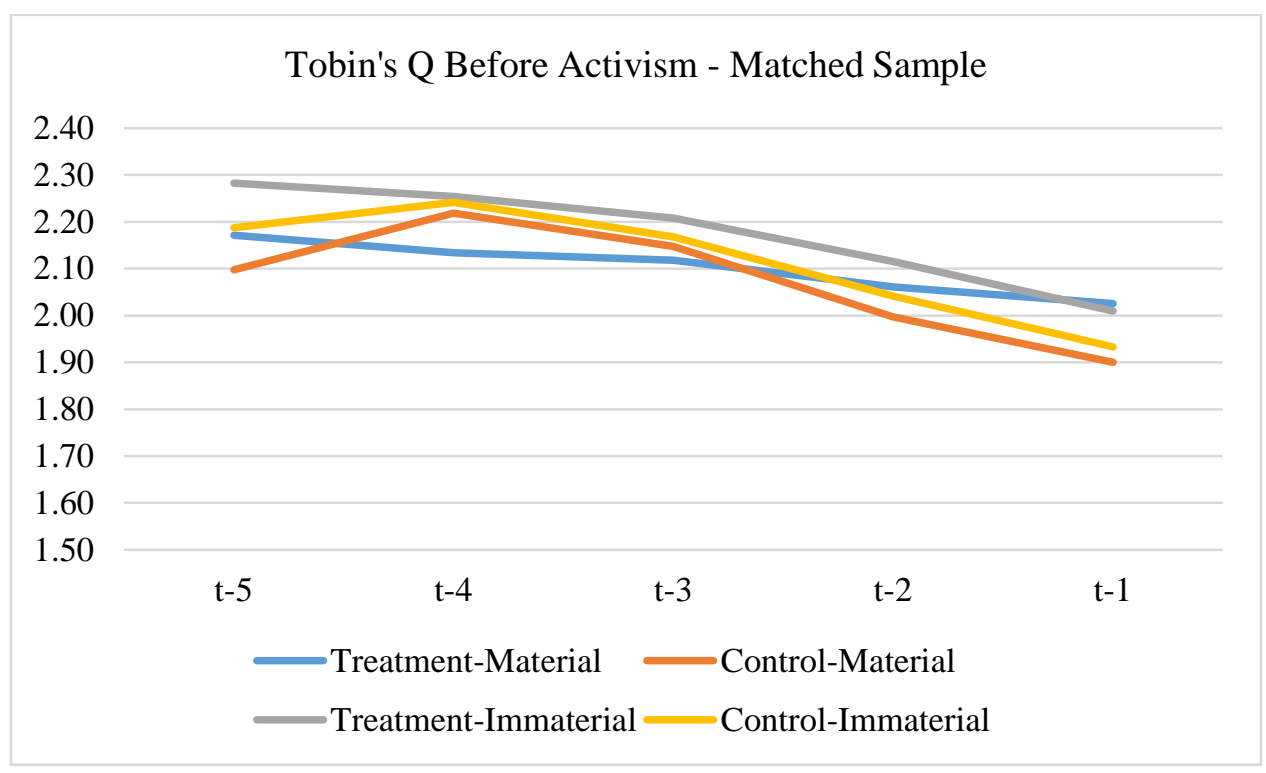


Figure 3a

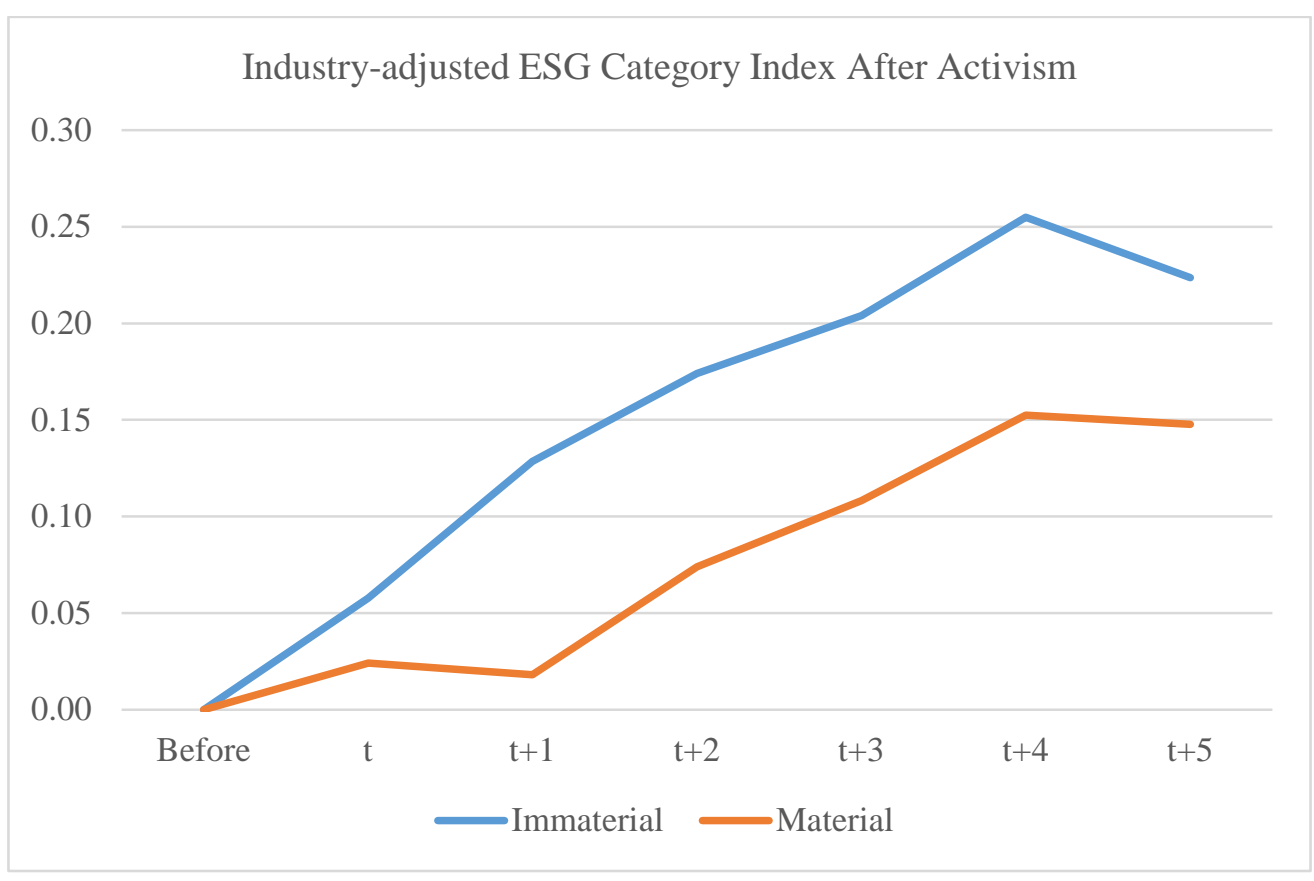

\section{Figure 3b}

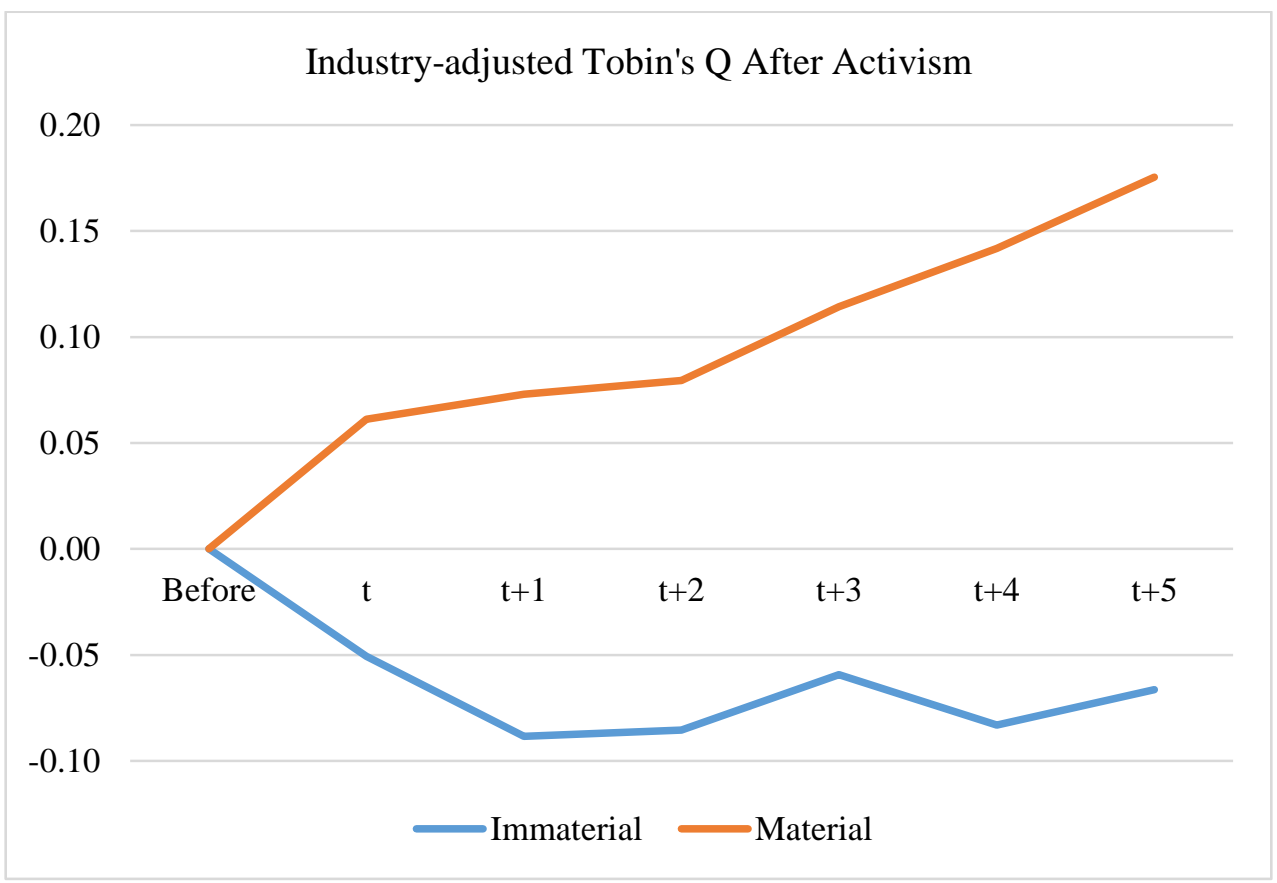




\section{Figure 4a}

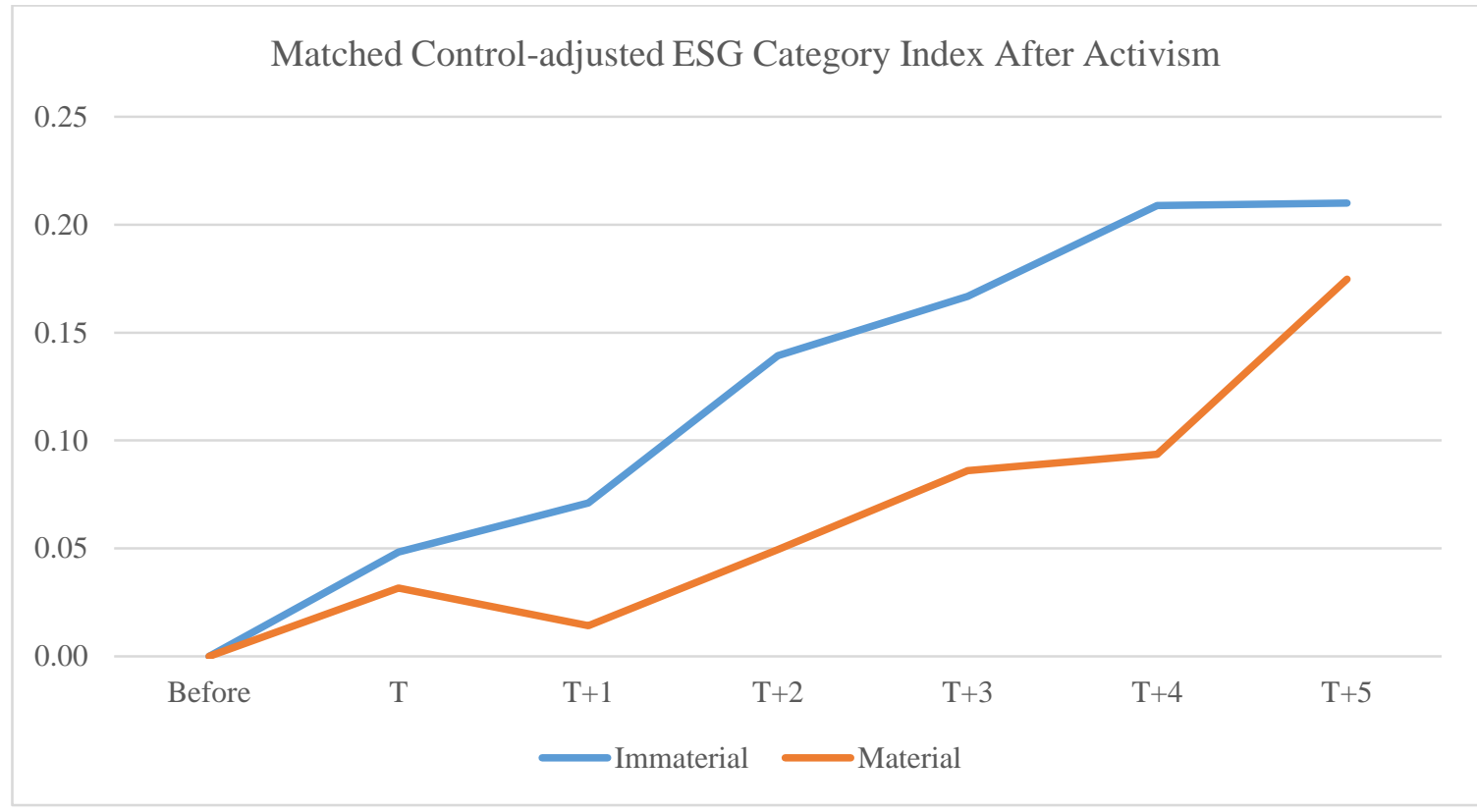

Figure 4b

Matched Control-adjusted Tobin's Q After Activism

0.15

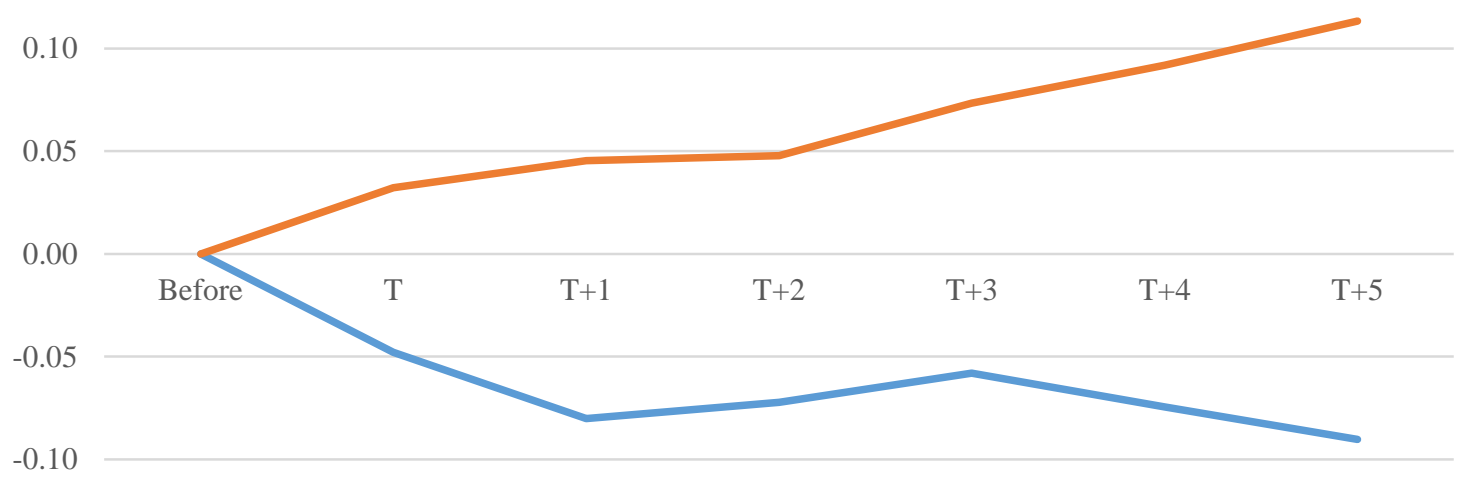

$-0.15$

Immaterial $\longrightarrow$ Material 
Table 1: Sample Selection

\begin{tabular}{lr}
\hline & \# of Proposals \\
\hline ISS Shareholder Proposal Data (1997-2012) & $\mathbf{1 4 , 9 8 6}$ \\
Less: corporate governance proposals & $-10,190$ \\
ESG Proposals & $\mathbf{4 , 7 9 6}$ \\
Less: omitted proposals & -816 \\
ESG Proposals Voted or Withdrawn & $\mathbf{3 , 9 8 0}$ \\
Less: sustainability reporting related resolutions & -305 \\
Less: missing firm identifiers & -62 \\
Less: missing proposal issues & -122 \\
Less: missing GICS industry information & -379 \\
Less: missing KLD data & -381 \\
Less: missing required financial information & -66 \\
\hline \hline Total & $\mathbf{2 , 6 6 5}$ \\
\hline
\end{tabular}

Table 2

Panel A: Frequency by Year

\begin{tabular}{cccc}
\hline Year & $\begin{array}{c}\text { \# of } \\
\text { Proposals }\end{array}$ & $\begin{array}{c}\text { \# of Material } \\
\text { Proposals }\end{array}$ & $\begin{array}{c}\text { \% Material } \\
\text { Proposals }\end{array}$ \\
\hline 1997 & 109 & 44 & $40 \%$ \\
1998 & 110 & 47 & $43 \%$ \\
1999 & 101 & 47 & $47 \%$ \\
2000 & 115 & 58 & $50 \%$ \\
2001 & 152 & 77 & $51 \%$ \\
2002 & 173 & 88 & $51 \%$ \\
2003 & 164 & 85 & $52 \%$ \\
2004 & 194 & 82 & $42 \%$ \\
2005 & 186 & 79 & $42 \%$ \\
2006 & 182 & 72 & $40 \%$ \\
2007 & 196 & 74 & $38 \%$ \\
2008 & 217 & 87 & $40 \%$ \\
2009 & 205 & 83 & $40 \%$ \\
2010 & 211 & 97 & $46 \%$ \\
2011 & 187 & 55 & $29 \%$ \\
2012 & 163 & 47 & $29 \%$ \\
\hline \hline Total & $\mathbf{2 , 6 6 5}$ & $\mathbf{1 , 1 2 2}$ & $\mathbf{4 2 \%}$ \\
\hline
\end{tabular}


Panel B: Frequency by Sector

\begin{tabular}{cccc}
\hline GICS Sector & \# of Proposals & \# of Material Proposals & \% Material Proposals \\
\hline Energy & 357 & 175 & $49 \%$ \\
Materials & 155 & 65 & $42 \%$ \\
Industrials & 392 & 127 & $32 \%$ \\
Consumer Discretionary & 475 & 208 & $44 \%$ \\
Consumer Staples & 387 & 177 & $46 \%$ \\
Health Care & 208 & 54 & $26 \%$ \\
Financials & 315 & 173 & $55 \%$ \\
Information Technology & 159 & 51 & $32 \%$ \\
Telecommunication Services & 51 & 23 & $45 \%$ \\
Utilities & 166 & 69 & $42 \%$ \\
\hline \hline Total & $\mathbf{2 , 6 6 5}$ & $\mathbf{1 , 1 2 2}$ & $\mathbf{4 2 \%}$ \\
\hline \hline
\end{tabular}

Panel C: Frequency by Sponsor

\begin{tabular}{cccc}
\hline Sponsor Type & \# of Proposals & \# of Material Proposals & \% Material Proposals \\
\hline Individual & 240 & 99 & $41 \%$ \\
Public Pension Fund & 466 & 127 & $27 \%$ \\
Religious Groups & 663 & 371 & $56 \%$ \\
SRI Fund & 604 & 255 & $42 \%$ \\
Special Interest Groups & 250 & 130 & $52 \%$ \\
Union Fund & 195 & 37 & $19 \%$ \\
Coalitions & 224 & 97 & $43 \%$ \\
Missing & 23 & 6 & $26 \%$ \\
\hline \hline Total & $\mathbf{2 , 6 6 5}$ & $\mathbf{1 , 1 2 2}$ & $\mathbf{4 2 \%}$ \\
\hline
\end{tabular}


Table 3a: Summary Statistics

\begin{tabular}{lcccccc}
\hline Variable & $\mathbf{N}$ & Mean & Std Dev & Q1 & Q2 & Q3 \\
\hline Ind. Adj. Category Index & 26,423 & -0.1229 & 1.2575 & -0.8444 & -0.0164 & 0.3448 \\
Ind. Adj. Tobin's Q & 26,423 & 0.5254 & 1.1104 & -0.0740 & 0.1701 & 0.7458 \\
Log(Assets) & 26,423 & 10.1054 & 1.6540 & 8.9849 & 10.1565 & 11.1220 \\
Capex/Assets & 26,423 & 0.0533 & 0.0420 & 0.0227 & 0.0440 & 0.0749 \\
R\&D/Assets & 26,423 & 0.0176 & 0.0310 & 0.0000 & 0.0019 & 0.0228 \\
Leverage & 26,423 & 0.2570 & 0.1528 & 0.1473 & 0.2435 & 0.3530 \\
Governance Proposal & 26,423 & 0.7269 & 0.4456 & 0.0000 & 1.0000 & 1.0000 \\
\hline
\end{tabular}

Table 3b: Correlation Matrix

(1)

(1) Ind. Adj. Category Index

(2) Ind. Adj. Tobin's Q

(3) $\log$ (Assets)

(4) Capex/Assets

(5) $\mathrm{R} \& \mathrm{D} /$ Assets

(6) Leverage

(7) Gov. Proposal

\begin{tabular}{cccccc}
1 & & & & & \\
$-0.0236^{*}$ & 1 & & & & \\
$0.0191^{*}$ & $-0.2097^{*}$ & 1 & & & \\
$0.0445^{*}$ & $0.1474^{*}$ & $-0.1885^{*}$ & 1 & & \\
$0.0943^{*}$ & $0.2175^{*}$ & $-0.0348^{*}$ & $-0.1185^{*}$ & 1 & \\
$0.0128^{*}$ & $-0.1638^{*}$ & $0.0502^{*}$ & $-0.0912^{*}$ & $-0.1964 *$ & 1 \\
-0.0048 & $-0.0755^{*}$ & $0.4286^{*}$ & $-0.0885^{*}$ & 0.0046 & 0.011 \\
\hline
\end{tabular}

Table $3 \mathrm{a}$ and Table $3 \mathrm{~b}$ present summary statistics and the univariate correlation matrix, respectively. Industry adjusted Category Index is the KLD score relating to the KLD category in the ESG proposal that the firm is engaged on, adjusted by the industry median. Post is a dummy variable that indicates the year and years after a firm is engaged on an ESG related issue. Material is a dummy variable that equals to one if the engagement is material, zero otherwise. Material X Post is an interaction between Material and Post. Industry adjusted Tobin's Q is (market value of equity - book value of equity + total assets)/total assets, adjusted by the industry median. Log of Assets is the natural logarithm of total assets. Capex/Assets is capital expenditure over total assets and R\&D/Assets is research and development expense over total assets. Leverage is (long-term debt + current debt)/total assets. Governance proposal is a dummy variable equal to one if any of the ESG proposals were accompanied by a corporate governance proposal in each of the years, and subsequent years, that a given firm was engaged on a traditional governance topic (i.e. executive compensation, anti-takeover provision, etc.), and zero otherwise. 
Table 4: Levels of Matching Variables for Samples of Engaged and Control Firms

\begin{tabular}{lcccc}
\hline & $\begin{array}{c}\text { Matched Treated } \\
\text { (engaged) }\end{array}$ & $\begin{array}{c}\text { Matched Control } \\
\text { (not engaged) }\end{array}$ & & \\
\hline ln(totalassets) for T-1 & $\underline{\text { Mean }}$ & $\underline{\text { Mean }}$ & $\underline{\text { Diff }}$ & $\frac{\text { t-stat }}{10.04}$ \\
Categoryindex forT-1 & -0.296 & -0.294 & 0.00 & 0.07 \\
Categoryindex for T-2 & -0.343 & -0.362 & 0.02 & 0.58 \\
Categoryindex for T-3 & -0.346 & -0.349 & 0.00 & 0.11 \\
Categoryindex forT-4 & -0.307 & -0.323 & 0.02 & 0.51 \\
Categoryindex for T-5 & -0.256 & -0.223 & -0.03 & 0.62 \\
& & & & \\
Tobin's Q for T-1 & 2.016 & 1.920 & 0.10 & 0.96 \\
Tobin's Q for T-2 & 2.093 & 2.023 & 0.07 & 0.74 \\
Tobin's Q for T-3 & 2.171 & 2.159 & 0.01 & 0.31 \\
Tobin's Q for T-4 & 2.204 & 2.232 & -0.03 & 0.44 \\
Tobin's Q for T-5 & 2.236 & 2.150 & 0.09 & 0.89 \\
\hline
\end{tabular}


Table 5a: Effect on Sustainability Performance - Industry Adjusted Performance

\begin{tabular}{|c|c|c|c|c|c|c|}
\hline \multirow[t]{3}{*}{ Dep Variable } & \multicolumn{6}{|c|}{ Industry Adj. Category Index } \\
\hline & \multicolumn{2}{|l|}{$(1)$} & \multicolumn{2}{|l|}{$(2)$} & \multicolumn{2}{|l|}{$(3)$} \\
\hline & Coefficient & $\mathrm{t}$ & Coefficient & $\mathrm{t}$ & Coefficient & $\mathrm{t}$ \\
\hline $\mathrm{T}$ & 0.0578 & 2.06 & 0.0619 & 2.22 & 0.0553 & 2.02 \\
\hline $\mathrm{T}+1$ & 0.1285 & 3.47 & 0.1353 & 3.61 & 0.1200 & 3.26 \\
\hline $\mathrm{T}+2$ & 0.1741 & 3.93 & 0.1827 & 3.99 & 0.1563 & 3.53 \\
\hline $\mathrm{T}+3$ & 0.2039 & 4.05 & 0.2142 & 4.08 & 0.1774 & 3.56 \\
\hline $\mathrm{T}+4$ & 0.2549 & 4.01 & 0.2674 & 4.05 & 0.2195 & 3.47 \\
\hline $\mathrm{T}+5$ & 0.2236 & 3.17 & 0.2380 & 3.22 & 0.1763 & 2.49 \\
\hline Material X T & -0.0337 & -0.55 & -0.0384 & -0.63 & -0.0363 & -0.61 \\
\hline Material X T+1 & -0.1105 & -1.51 & -0.1166 & -1.61 & -0.1093 & -1.53 \\
\hline Material X T+2 & -0.1002 & -1.34 & -0.1061 & -1.44 & -0.0960 & -1.32 \\
\hline Material X T+3 & -0.0958 & -1.33 & -0.1008 & -1.42 & -0.0933 & -1.34 \\
\hline Material X T+4 & -0.1024 & -1.27 & -0.1085 & -1.36 & -0.1026 & -1.30 \\
\hline Material X T+5 & -0.0758 & -0.86 & -0.0822 & -0.95 & -0.0775 & -0.90 \\
\hline Log(Assets) & & & 0.0379 & 0.44 & 0.0565 & 0.67 \\
\hline Capex/Assets & & & 1.4629 & 1.52 & 1.4466 & 1.56 \\
\hline $\mathrm{R} \& \mathrm{D} /$ Assets & & & 1.0322 & 0.46 & 1.0447 & 0.47 \\
\hline Leverage & & & -0.0031 & -0.02 & -0.0074 & -0.04 \\
\hline Governance Proposals & & & & & -0.3038 & -4.13 \\
\hline Number of Obs & 26423 & & 26423 & & 26423 & \\
\hline Adjusted R-Squared & 0.5695 & & 0.5695 & & 0.5731 & \\
\hline Year F.E. & Yes & & Yes & & Yes & \\
\hline Firm-Proposal F.E. & Yes & & Yes & & Yes & \\
\hline
\end{tabular}

Dependent variable is the Industry adjusted Category Index. Industry adjusted Category Index is the KLD score relating to the KLD category in the ESG proposal that the firm is engaged on, adjusted by the industry median. T through $\mathrm{T}+5$ are event-time dummies indicating the base year of the engagement to five years after the engagement. Material is a dummy variable that equals to one if the engagement is material, zero otherwise. Material X Ts are interactions of event-time dummies with the "Material" indicator. Log of Assets is the natural logarithm of total assets. Capex/Assets is capital expenditure over total assets and R\&D/Assets is research and development expense over total assets. Leverage is (long-term debt + current debt)/total assets. Governance proposal is a dummy variable equal to one if any of the ESG proposals were accompanied by a corporate governance proposal in each of the years, and subsequent years, that a given firm was engaged on a traditional governance topic (i.e. executive compensation, anti-takeover provision, and etc.), and zero otherwise. Standard errors are robust and clustered at the firm-level. 
Table 5b: Effect on Sustainability Performance - Matched Control Adjusted Performance

\begin{tabular}{|c|c|c|c|c|c|c|}
\hline \multirow[t]{3}{*}{ Dep Variable } & \multicolumn{6}{|c|}{ Match Adj. Category Index } \\
\hline & \multicolumn{2}{|l|}{ (1) } & \multicolumn{2}{|l|}{ (2) } & \multicolumn{2}{|l|}{ (3) } \\
\hline & Coefficient & $\mathrm{t}$ & Coefficient & $\mathrm{t}$ & Coefficient & $\mathrm{t}$ \\
\hline $\mathrm{T}$ & 0.0483 & 1.64 & 0.0522 & 1.76 & 0.0435 & 1.51 \\
\hline $\mathrm{T}+1$ & 0.0710 & 1.66 & 0.0772 & 1.77 & 0.0594 & 1.41 \\
\hline $\mathrm{T}+2$ & 0.1393 & 2.65 & 0.1467 & 2.68 & 0.1121 & 2.15 \\
\hline $\mathrm{T}+3$ & 0.1667 & 2.87 & 0.1758 & 2.91 & 0.1322 & 2.31 \\
\hline $\mathrm{T}+4$ & 0.2089 & 2.73 & 0.2199 & 2.78 & 0.1624 & 2.14 \\
\hline $\mathrm{T}+5$ & 0.2100 & 2.44 & 0.2224 & 2.48 & 0.1500 & 1.76 \\
\hline Material X T & -0.0166 & -0.26 & -0.0206 & -0.33 & -0.0203 & -0.34 \\
\hline Material X T+1 & -0.0569 & -0.70 & -0.0616 & -0.76 & -0.0575 & -0.72 \\
\hline Material X T+2 & -0.0898 & -1.06 & -0.0946 & -1.13 & -0.0860 & -1.05 \\
\hline Material X T+3 & -0.0807 & -0.93 & -0.0847 & -0.99 & -0.0789 & -0.95 \\
\hline Material X T+4 & -0.1153 & -1.23 & -0.1212 & -1.31 & -0.1170 & -1.29 \\
\hline Material X T+5 & -0.0353 & -0.31 & -0.0417 & -0.37 & -0.0360 & -0.32 \\
\hline Log(Assets) & & & 0.0368 & 0.42 & 0.0612 & 0.70 \\
\hline Capex/Assets & & & 1.2334 & 1.24 & 1.2151 & 1.27 \\
\hline $\mathrm{R} \& \mathrm{D} /$ Assets & & & 1.1972 & 0.59 & 1.1236 & 0.56 \\
\hline Leverage & & & 0.0303 & 0.13 & 0.0289 & 0.13 \\
\hline Governance Proposals & & & & & -0.3365 & -4.92 \\
\hline Number of Obs & 22426 & & 22426 & & 22426 & \\
\hline Adjusted R-Squared & 0.6026 & & 0.603 & & 0.6069 & \\
\hline Year F.E. & Yes & & Yes & & Yes & \\
\hline Firm-Proposal F.E. & Yes & & Yes & & Yes & \\
\hline
\end{tabular}

Dependent variable is the Matched adjusted Category Index. Matched adjusted Category Index is the KLD score relating to the KLD category in the ESG proposal that the firm is engaged on, adjusted by the same KLD category KLD score for a propensity scored matched control firm. T through $\mathrm{T}+5$ are event-time dummies indicating the base year of the engagement to five years after the engagement. Material is a dummy variable that equals to one if the engagement is material, zero otherwise. Material X Ts are interactions of event-time dummies with the "Material" indicator. Log of Assets is the natural logarithm of total assets. Capex/Assets is capital expenditure over total assets and $R \& D / A s s e t s$ is research and development expense over total assets. Leverage is (long-term debt + current debt)/total assets. Governance proposal is a dummy variable equal to one if any of the ESG proposals were accompanied by a corporate governance proposal in each of the years, and subsequent years, that a given firm was engaged on a traditional governance topic (i.e. executive compensation, anti-takeover provision, and etc.), and zero otherwise. Standard errors are robust and clustered at the firm-level. 
Table 6a: Effect on Market Valuation - Industry Adjusted Performance

\begin{tabular}{|c|c|c|c|c|c|c|c|c|}
\hline \multirow{4}{*}{$\begin{array}{l}\text { Sample } \\
\text { Dep Variable }\end{array}$} & \multicolumn{6}{|c|}{$A l l$} & \multicolumn{2}{|c|}{$\begin{array}{l}\text { Excluding firms with both materiat } \\
\text { \& immaterial proposals within the } \\
\text { same } 2 \text { year }\end{array}$} \\
\hline & \multicolumn{8}{|c|}{ Industry Adj. Tobin's $Q$} \\
\hline & \multicolumn{2}{|l|}{ (1) } & \multicolumn{2}{|l|}{$(2)$} & \multicolumn{2}{|l|}{$(3)$} & \multicolumn{2}{|l|}{ (4) } \\
\hline & Coefficient & $\mathrm{t}$ & Coefficient & $\mathrm{t}$ & Coefficient & $\mathrm{t}$ & Coefficient & $\mathrm{t}$ \\
\hline $\mathrm{T}$ & -0.0430 & -2.02 & -0.0468 & -2.39 & -0.0461 & -2.32 & -0.0507 & -1.79 \\
\hline $\mathrm{T}+1$ & -0.0592 & -2.04 & -0.0753 & -2.73 & -0.0737 & -2.63 & -0.0884 & -2.35 \\
\hline $\mathrm{T}+2$ & -0.0432 & -1.13 & -0.0719 & -2.05 & -0.0692 & -1.93 & -0.0855 & -1.75 \\
\hline $\mathrm{T}+3$ & -0.0234 & -0.48 & -0.0616 & -1.42 & -0.0577 & -1.31 & -0.0594 & -0.91 \\
\hline $\mathrm{T}+4$ & -0.0247 & -0.42 & -0.0667 & -1.27 & -0.0616 & -1.19 & -0.0830 & -1.14 \\
\hline $\mathrm{T}+5$ & -0.0248 & -0.37 & -0.0738 & -1.21 & -0.0673 & -1.13 & -0.0664 & -0.78 \\
\hline Material X T & 0.0962 & 2.40 & 0.0722 & 2.17 & 0.0720 & 2.17 & 0.1118 & 2.22 \\
\hline Material X T+1 & 0.1167 & 2.65 & 0.0968 & 2.55 & 0.0960 & 2.54 & 0.1614 & 2.86 \\
\hline Material X T+2 & 0.1085 & 2.22 & 0.0975 & 2.31 & 0.0964 & 2.31 & 0.1650 & 2.44 \\
\hline Material X T+3 & 0.1022 & 1.77 & 0.0996 & 2.03 & 0.0988 & 2.03 & 0.1737 & 2.18 \\
\hline Material X T+4 & 0.1208 & 1.75 & 0.1039 & 1.79 & 0.1032 & 1.79 & 0.2249 & 2.44 \\
\hline Material X T+5 & 0.1348 & 1.69 & 0.1018 & 1.50 & 0.1013 & 1.51 & 0.2418 & 2.21 \\
\hline Log(Assets) & & & -0.5754 & -7.58 & -0.5774 & -7.70 & -0.5499 & -6.38 \\
\hline Capex/Assets & & & 3.8313 & 4.16 & 3.8330 & 4.17 & 3.8314 & 4.46 \\
\hline R\&D/Assets & & & 12.7390 & 2.65 & 12.7377 & 2.63 & 12.3261 & 2.45 \\
\hline Leverage & & & -1.5549 & -4.07 & -1.5545 & -4.08 & -1.1814 & -4.04 \\
\hline Governance Proposals & & & & & 0.0321 & 0.37 & -0.0265 & -0.33 \\
\hline Number of Obs & 26423 & & 26423 & & 26423 & & 14297 & \\
\hline Adjusted R-Squared & 0.6915 & & 0.7385 & & 0.7386 & & 0.7374 & \\
\hline Year F.E. & Yes & & Yes & & Yes & & Yes & \\
\hline Firm-Proposal F.E. & Yes & & Yes & & Yes & & Yes & \\
\hline
\end{tabular}

Dependent variable is the Industry adjusted Tobin's Q, which is (market value of equity-book value of equity +total assets)/total assets adjusted by the industry median. T through $\mathrm{T}+5$ are event-time dummies indicating the base year of the engagement to five years after the engagement. Material is a dummy variable that equals to one if the engagement is material, zero otherwise. Material X Ts are interactions of event-time dummies with the "Material" indicator. Log of Assets is the natural logarithm of total assets. Capex/Assets is capital expenditure over total assets and R\&D/Assets is research and development expense over total assets. Leverage is (long-term debt + current debt)/total assets. Governance proposal is a dummy variable equal to one if any of the ESG proposals were accompanied by a corporate governance proposal in each of the years, and subsequent years, that a given firm was engaged on a traditional governance topic (i.e. executive compensation, anti-takeover provision, and etc.), and zero otherwise. Standard errors are robust and clustered at the firm-level. 
Table 6b: Effect on Market Valuation - Matched Control Adjusted Performance

\begin{tabular}{|c|c|c|c|c|c|c|c|c|}
\hline \multirow{4}{*}{$\begin{array}{l}\text { Sample } \\
\text { Dep Var }\end{array}$} & \multicolumn{6}{|c|}{ All } & \multicolumn{2}{|c|}{$\begin{array}{c}\text { Excluding firms with both material } \\
\text { \& immaterial proposals within the } \\
\text { same } 2 \text { year }\end{array}$} \\
\hline & \multicolumn{8}{|c|}{ Match Adj. Tobin's $Q$} \\
\hline & $(1)$ & & $(2)$ & & $(3)$ & & $(4)$ & \\
\hline & Coefficient & $\mathrm{t}$ & Coefficient & $\mathrm{t}$ & Coefficient & $\mathrm{t}$ & Coefficient & $\mathrm{t}$ \\
\hline $\mathrm{T}$ & -0.0371 & -2.25 & -0.0382 & -2.45 & -0.0375 & -2.38 & -0.0479 & -2.15 \\
\hline $\mathrm{T}+1$ & -0.0548 & -2.51 & -0.0646 & -3.03 & -0.0633 & -2.96 & -0.0803 & -2.60 \\
\hline $\mathrm{T}+2$ & -0.0366 & -1.27 & -0.0573 & -2.10 & -0.0547 & -1.98 & -0.0723 & -1.83 \\
\hline $\mathrm{T}+3$ & -0.0331 & -0.92 & -0.0611 & -1.88 & -0.0578 & -1.81 & -0.0581 & -1.97 \\
\hline $\mathrm{T}+4$ & -0.0322 & -0.71 & -0.0637 & -1.60 & -0.0594 & -1.57 & -0.0745 & -2.40 \\
\hline $\mathrm{T}+5$ & -0.0592 & -1.08 & -0.0900 & -1.88 & -0.0846 & -1.89 & -0.0904 & -1.88 \\
\hline Material X T & 0.0776 & 2.40 & 0.0590 & 2.10 & 0.0590 & 2.11 & 0.0802 & 1.97 \\
\hline Material X T+1 & 0.0974 & 2.58 & 0.0803 & 2.36 & 0.0800 & 2.37 & 0.1255 & 2.45 \\
\hline Material X T+2 & 0.0821 & 1.82 & 0.0728 & 1.79 & 0.0722 & 1.79 & 0.1202 & 1.83 \\
\hline Material X T+3 & 0.0847 & 1.58 & 0.0802 & 1.73 & 0.0797 & 1.74 & 0.1315 & 2.62 \\
\hline Material X T+4 & 0.1013 & 1.59 & 0.0796 & 1.44 & 0.0793 & 1.45 & 0.1664 & 2.21 \\
\hline Material X T+5 & 0.1337 & 1.82 & 0.0985 & 1.52 & 0.0981 & 1.53 & 0.2038 & 1.98 \\
\hline Log(Assets) & & & -0.4420 & -9.01 & -0.4438 & -9.15 & -0.3815 & -7.68 \\
\hline Capex/Assets & & & 3.1432 & 4.95 & 3.1446 & 4.96 & 3.0464 & 5.05 \\
\hline R\&D/Assets & & & 7.2423 & 2.35 & 7.2478 & 2.35 & 6.8189 & 1.97 \\
\hline Leverage & & & -1.1767 & -4.10 & -1.1765 & -4.11 & -0.8144 & -3.46 \\
\hline Governance Proposals & & & & & 0.0252 & 0.42 & 0.0097 & 0.17 \\
\hline Number of Obs & 22426 & & 22426 & & 22426 & & 12006 & \\
\hline Adjusted R-Squared & 0.7436 & & 0.7864 & & 0.7865 & & 0.7739 & \\
\hline Year F.E. & Yes & & Yes & & Yes & & Yes & \\
\hline Firm-Proposal F.E. & Yes & & Yes & & Yes & & Yes & \\
\hline
\end{tabular}

Dependent variable is the Matched Control adjusted Tobin's Q, which is (market value of equity-book value of equity +total assets)/total assets adjusted by the Tobin's Q of the propensity score matched control firm. T through T+5 are event-time dummies indicating the base year of the engagement to five years after the engagement. Material is a dummy variable that equals to one if the engagement is material, zero otherwise. Material X Ts are interactions of event-time dummies 
with the "Material" indicator. Log of Assets is the natural logarithm of total assets. Capex/Assets is capital expenditure over total assets and R\&D/Assets is research and development expense over total assets. Leverage is (long-term debt + current debt)/total assets. Governance proposal is a dummy variable equal to one if any of the ESG proposals were accompanied by a corporate governance proposal in each of the years, and subsequent years, that a given firm was engaged on a traditional governance topic (i.e. executive compensation, anti-takeover provision, and etc.), and zero otherwise. Standard errors are robust and clustered at the firm-level. 
Table 7: Effect on Sustainability Performance- Why firms increase performance on immaterial issues

Panel A: Agency Explanations

\begin{tabular}{|c|c|c|c|c|}
\hline \multirow{3}{*}{$\begin{array}{l}\text { Dep Variable } \\
\text { Interaction Variable }\end{array}$} & \multicolumn{4}{|c|}{ Industry Adj. Category Index } \\
\hline & \multicolumn{2}{|c|}{$\begin{array}{c}\text { ROA Above Q3 } \\
\text { (1) }\end{array}$} & \multicolumn{2}{|c|}{$\begin{array}{c}\text { E-Index below Q1 } \\
\text { (2) }\end{array}$} \\
\hline & Coefficient & $\mathrm{t}$ & Coefficient & $\mathrm{t}$ \\
\hline $\mathrm{T}$ & 0.0063 & 0.20 & 0.0574 & 2.15 \\
\hline $\mathrm{T}+1$ & 0.0686 & 1.62 & 0.1229 & 3.44 \\
\hline $\mathrm{T}+2$ & 0.1177 & 2.29 & 0.1558 & 3.64 \\
\hline $\mathrm{T}+3$ & 0.1335 & 2.32 & 0.1841 & 3.80 \\
\hline $\mathrm{T}+4$ & 0.1753 & 2.48 & 0.2167 & 3.57 \\
\hline $\mathrm{T}+5$ & 0.1217 & 1.56 & 0.1671 & 2.47 \\
\hline (High ROA or Low E-index) X T & 0.1807 & 3.15 & -0.2049 & -1.67 \\
\hline (High ROA or Low E-index) X T+1 & 0.1804 & 2.63 & -0.3329 & -2.39 \\
\hline (High ROA or Low E-index) X T+2 & 0.1205 & 1.61 & -0.3316 & -1.73 \\
\hline (High ROA or Low E-index) X T+3 & 0.1445 & 2.06 & -0.6496 & -4.46 \\
\hline (High ROA or Low E-index) X T+4 & 0.1205 & 1.55 & -0.5765 & -2.80 \\
\hline (High ROA or Low E-index) X T+5 & 0.1465 & 1.82 & -0.4787 & -3.02 \\
\hline Log(Assets) & 0.0396 & 0.54 & 0.0551 & 0.72 \\
\hline Capex/Assets & 1.2819 & 1.51 & 1.3189 & 1.42 \\
\hline R\&D/Assets & 0.8208 & 0.39 & 1.0057 & 0.46 \\
\hline Leverage & -0.0094 & -0.05 & -0.0145 & -0.08 \\
\hline Governance Proposals & -0.2979 & -4.22 & -0.2954 & -4.20 \\
\hline Number of Obs & 26619 & & 26619 & \\
\hline Adjusted R-Squared & 0.570 & & 0.5698 & \\
\hline (All Portfolios) X Material X Ts & Yes & & Yes & \\
\hline Year F.E. & Yes & & Yes & \\
\hline Firm-Proposal F.E. & Yes & & Yes & \\
\hline
\end{tabular}

Dependent variable is the Industry adjusted Category Index. Controls are defined as the previous tables. For Column 1, High ROA is an indicator variable equal to one if industry adjusted ROA is above the third quartile, zero if otherwise. For Column 2, Low E-index is an indicator variable equal to one if Entrenchment Index is below the first quartile, zero if otherwise. High ROA or Low E-index X Ts are interactions of event-time dummies with the "High ROA" or "Low E-index" indicator. Material X Ts and interactions of event-time dummies with the "Material" and "High ROA" or "Low E-index" indicator (e.g. High ROA X Material X Ts) are suppressed for brevity. Standard errors are robust and clustered at the firm-level. 


\begin{tabular}{|c|c|c|}
\hline \multirow[t]{2}{*}{ Dep Variable } & \multicolumn{2}{|c|}{$\begin{array}{c}\text { Industry Adj. Category } \\
\text { Index }\end{array}$} \\
\hline & Coefficient & $\mathrm{t}$ \\
\hline 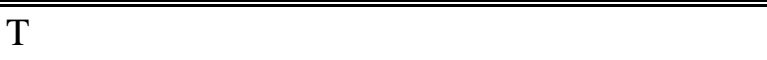 & -0.0609 & -1.28 \\
\hline $\mathrm{T}+1$ & -0.0251 & -0.31 \\
\hline $\mathrm{T}+2$ & -0.0282 & -0.32 \\
\hline $\mathrm{T}+3$ & 0.0200 & 0.23 \\
\hline $\mathrm{T}+4$ & 0.0516 & 0.52 \\
\hline $\mathrm{T}+5$ & -0.0281 & -0.24 \\
\hline (High on Immaterial \& High on Material) X T & 0.3248 & 5.55 \\
\hline (High on Immaterial \& High on Material) $\mathrm{X} T+1$ & 0.3405 & 3.56 \\
\hline (High on Immaterial \& High on Material) $\mathrm{X} \mathrm{T}+2$ & 0.3201 & 2.98 \\
\hline (High on Immaterial \& High on Material) $\mathrm{X} T+3$ & 0.2914 & 2.48 \\
\hline (High on Immaterial \& High on Material) $\mathrm{X} T+4$ & 0.3229 & 2.71 \\
\hline (High on Immaterial \& High on Material) $\mathrm{X} T+5$ & 0.4208 & 3.08 \\
\hline (High on Immaterial \& Low on Material) X T & 0.1734 & 2.47 \\
\hline (High on Immaterial \& Low on Material) X T+1 & 0.1596 & 1.64 \\
\hline (High on Immaterial \& Low on Material) X T+2 & 0.1942 & 2.02 \\
\hline (High on Immaterial \& Low on Material) $\mathrm{X} T+3$ & 0.1280 & 1.25 \\
\hline (High on Immaterial \& Low on Material) X T +4 & 0.1140 & 0.91 \\
\hline (High on Immaterial \& Low on Material) X T +5 & 0.0245 & 0.19 \\
\hline $\log ($ Asset $)$ & 0.0865 & 1.21 \\
\hline Capex/Assets & 2.1481 & 2.08 \\
\hline R\&D/Assets & 1.9867 & 0.96 \\
\hline Leverage & -0.2138 & -1.13 \\
\hline Governance Proposals & -0.1802 & -3.26 \\
\hline Number of Obs & 24288 & \\
\hline Adjusted R-Squared & 0.6374 & \\
\hline (Low on Immaterial \& Low on Material) X Ts & Yes & \\
\hline (All Portfolios) X Material X Ts & Yes & \\
\hline Year F.E. & Yes & \\
\hline Firm-Proposal F.E. & Yes & \\
\hline
\end{tabular}

Dependent variable is the Industry adjusted Category Index. "High on Immaterial \& High on Material" is an indicator variable equal to one for firms that have high performance on immaterial issues and high performance on material issues, zero if otherwise. "High on Immaterial \& Low on Material" is an indicator variable equal one for a portfolio of firms who has high performance on immaterial issues and low performance on material issues, zero if otherwise. "Low on Immaterial \& Low on Material" is an indicator variable equal to one for a portfolio of firms who has low performance on immaterial issues and low performance on material issues, zero if otherwise. Material X Ts and interactions of event-time dummies with the "Material" and portfolio indicators (e.g. High on Immaterial \& High on Material X Material X Ts) are suppressed for brevity. The Table presents results when median materiality and immateriality scores are used to classify high and low firms. All interactions and control variables are defined consistent to previous tables. Standard errors are robust and clustered at the firm-level. 
Table 8: Effect on Sustainability Performance or Market Valuation- Additional Tests

\begin{tabular}{|c|c|c|c|c|c|c|c|c|}
\hline \multirow{5}{*}{$\begin{array}{l}\text { Sample } \\
\text { Dep Variable } \\
\text { Cross Section }\end{array}$} & \multicolumn{6}{|c|}{ Excluding firms with both material \& immaterial proposals within the same 2 year } & \multirow{2}{*}{\multicolumn{2}{|c|}{$\begin{array}{c}\text { All } \\
\text { Industry Adj. Category Index } \\
\end{array}$}} \\
\hline & \multicolumn{4}{|c|}{ Industry Adj. Tobin's $Q$} & \multirow{2}{*}{\multicolumn{2}{|c|}{$\begin{array}{c}\text { Industry Adj. Tobin's } Q \\
\text { Withdraw }=0\end{array}$}} & & \\
\hline & \multicolumn{2}{|c|}{ Category Index High } & \multicolumn{2}{|c|}{ Category Index Low } & & & \multirow{2}{*}{\multicolumn{2}{|c|}{$\frac{\text { Withdraw }=0}{(4)}$}} \\
\hline & (1) & & (2) & & \multicolumn{2}{|c|}{$(3)$} & & \\
\hline & Coefficient & $\mathrm{t}$ & Coefficient & $\mathrm{t}$ & Coefficient & $\mathrm{t}$ & Coefficient & $\mathrm{t}$ \\
\hline$\overline{\mathrm{T}}$ & -0.0345 & 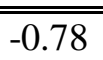 & -0.0689 & 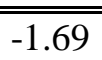 & 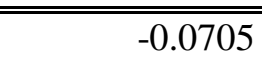 & 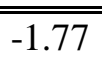 & 0.0750 & 2.09 \\
\hline $\mathrm{T}+1$ & -0.0777 & -1.27 & -0.0996 & -1.80 & -0.1284 & -2.38 & 0.1262 & 2.66 \\
\hline $\mathrm{T}+2$ & -0.0787 & -1.01 & -0.0879 & -1.19 & -0.1460 & -2.07 & 0.1348 & 2.49 \\
\hline$T+3$ & -0.0505 & -0.54 & -0.0661 & -0.70 & -0.1492 & -1.61 & 0.1541 & 2.33 \\
\hline $\mathrm{T}+4$ & -0.0688 & -0.67 & -0.0896 & -0.84 & -0.1552 & -1.48 & 0.2090 & 2.49 \\
\hline $\mathrm{T}+5$ & -0.0461 & -0.41 & -0.0733 & -0.56 & -0.1259 & -1.04 & 0.1596 & 1.62 \\
\hline Material X T & 0.0922 & 1.42 & 0.1375 & 2.17 & 0.1226 & 1.77 & -0.0759 & -1.02 \\
\hline Material X T+1 & 0.1258 & 1.68 & 0.2028 & 2.95 & 0.2007 & 2.52 & -0.1647 & -1.94 \\
\hline Material X T+2 & 0.1466 & 1.88 & 0.1874 & 2.07 & 0.2173 & 2.17 & -0.1232 & -1.40 \\
\hline Material X T+3 & 0.2018 & 2.24 & 0.1568 & 1.44 & 0.2768 & 2.44 & -0.0711 & -0.85 \\
\hline Material X T+4 & 0.3007 & 2.87 & 0.1573 & 1.22 & 0.3163 & 2.46 & -0.1004 & -1.03 \\
\hline Material X T+5 & 0.3287 & 2.78 & 0.1576 & 0.98 & 0.3189 & 2.16 & -0.0700 & -0.66 \\
\hline Log(Assets) & -0.5013 & -5.63 & -0.5764 & -4.96 & -0.6297 & -5.80 & 0.0879 & 0.83 \\
\hline Capex/Assets & 3.8322 & 3.64 & 3.6625 & 3.67 & 3.8024 & 4.09 & 2.0520 & 1.86 \\
\hline R\&D/Assets & 13.0755 & 2.70 & 10.5385 & 1.51 & 11.3065 & 2.07 & 0.0436 & 0.01 \\
\hline Leverage & -1.4097 & -3.78 & -1.0053 & -3.17 & -1.3580 & -3.88 & -0.1637 & -0.67 \\
\hline Governance Proposals & -0.0359 & -0.40 & -0.0139 & -0.15 & -0.0003 & 0.00 & -0.3516 & -3.80 \\
\hline Number of Obs & 7159 & & 7138 & & 8552 & & 17361 & \\
\hline Adjusted R-Squared & 0.7234 & & 0.7538 & & 0.7526 & & 0.5841 & \\
\hline Year F.E. & Yes & & Yes & & Yes & & Yes & \\
\hline Firm-Proposal F.E. & Yes & & Yes & & Yes & & Yes & \\
\hline
\end{tabular}

Dependent variable is the Industry adjusted Tobin's Q and Industry adjusted Category Index. T through T+5 are event-time dummies indicating the base year of the engagement to five years after the engagement. Material is a dummy variable that equals to one if the engagement is material, zero otherwise. Material X Ts are interactions of event-time dummies with the "Material" indicator. Log of Assets is the natural logarithm of total assets. Capex/Assets is capital expenditure over total assets and R\&D/Assets is research and development expense over total assets. Leverage is (long-term debt + current debt)/total assets. Governance proposal is a dummy variable equal to one if any of the ESG proposals were accompanied by a corporate governance proposal in each of the years, and subsequent years, that a given firm was engaged on a traditional governance topic (i.e. executive compensation, anti-takeover provision, and etc.), and zero otherwise. Standard errors are robust and clustered at the firm-level. 
Appendix I

SASB's Standard Setting Process

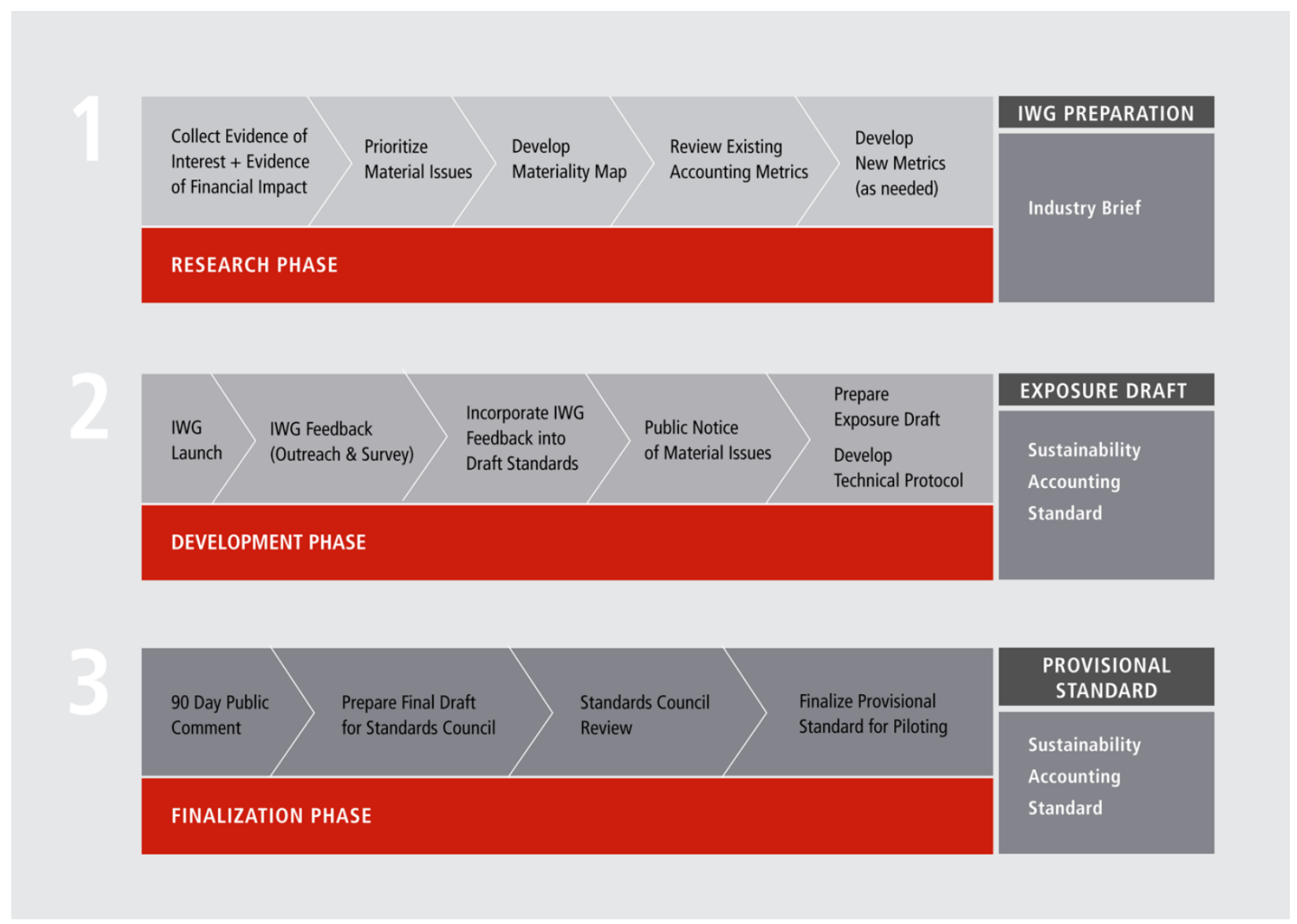

Source: Sustainability Accounting Standards Board. www.sasb.org 


\section{Appendix II}

\section{SASB's Materiality Process}

For each topic, SASB conducts an evidence of materiality test, the results of which ultimately are debated and reviewed by the Standards Council after industry working groups composed of industry experts have provided their input. The test has three components: evidence of interest, evidence of financial impact, and forward impact adjustment.

The interest test has two components, a heat map score and an industry working group score. The heat map score is derived from a search for relevant keywords in documents stored on Bloomberg servers and indicates the relative importance of the issue among SASB's initial list of 43 generic sustainability issues. Evidence of interest is gathered by searching tens of thousands of industry-related documentsForm 10-Ks, shareholder resolutions, CSR reports, media and SEC comment letters-for key words related to 30 general sustainability issues. The industry working group score signals the percentage of industry working group members that found the issue to be material. SASB convenes an industry working group to provide feedback on the disclosure items and accounting metrics identified in the initial research phase. The industry working groups are composed of balanced representation from corporations, market participants, and public interest intermediaries. Primary industry working group feedback is collected via an online survey. After the conclusion of online survey, SASB's research team conducts outreach to industry working group members to gain additional insight.

The financial impact test uses a value framework developed by McKinsey and seeks to identify evidence of financial impact on revenues/costs, assets/liabilities, or cost of capital from the focal issue in an industry. Evidence of financial impact is gathered by examining sell side research, investor call transcripts, third party case studies, anecdotal evidence, and news articles. After identifying a minimum set of disclosure topics for an industry, for which there is solid evidence of both investor interest and financial impact, SASB identifies and documents existing metrics and practices used to account for performance on each disclosure topic. Any evidences found are publically disseminated through industry-specific industry briefs. 
The forward-looking impact test assesses the future probability and magnitude of financial impact from the focal issue to capture issues that may fail the financial impact test but may still be relevant for investors. The forward-looking impact test also assesses whether the issue will generate significant externalities in the future. However, it should be noted that to date the forward looking impact adjustment has been rarely used by SASB to switch a topic from immaterial to material. After the consultation with the industry working group has finished, SASB prepares an Exposure Draft Standard with accounting metrics and technical protocols for each of the disclosure topics.

In the next phase, SASB releases the Exposure Draft Standard for a 90 day public comment period. At this time, any member of the public can download the Exposure Draft Standard from SASB's website and provide feedback via a letter. At the conclusion of the public comment period, SASB incorporates feedback received into the standard. The Standards Council then reviews the standard to ensure consistency, completeness and accuracy. With the Standards Council's final review, the Provisional Standard is considered complete. The Provisional Sustainability Accounting Standard is then published and made available to the public. 


\section{Appendix III}

Sector-level Materiality Map

\begin{tabular}{|c|c|c|c|c|c|c|c|c|c|c|}
\hline Issues & Health Care & Financials & $\begin{array}{c}\text { Technology \& } \\
\text { Communications }\end{array}$ & Non-Renewable & Transportation & Services & $\begin{array}{c}\text { Resource } \\
\text { Transformation }\end{array}$ & Consumption & $\begin{array}{l}\text { Renewables \& } \\
\text { Alt. Energy }\end{array}$ & Infrastructure \\
\hline \multicolumn{11}{|l|}{ Environment } \\
\hline \multicolumn{11}{|l|}{ GHG emissions } \\
\hline \multicolumn{11}{|l|}{ Air quality } \\
\hline \multicolumn{11}{|l|}{ Energy mgm't } \\
\hline \multicolumn{11}{|l|}{ Fuel mgm't } \\
\hline \multicolumn{11}{|c|}{ Water / wastewater mgm't } \\
\hline \multicolumn{11}{|c|}{ Waste / hazardous materials mgm't } \\
\hline \multicolumn{11}{|l|}{ Biodiversity impacts } \\
\hline \multicolumn{11}{|l|}{ Social Capital } \\
\hline \multicolumn{11}{|c|}{ Human rights / community relations } \\
\hline \multicolumn{11}{|c|}{ Access / affordability } \\
\hline \multicolumn{11}{|l|}{ Customer welfare } \\
\hline \multicolumn{11}{|c|}{ Data security / customer privacy } \\
\hline \multicolumn{11}{|c|}{ Fair disclosure / labeling } \\
\hline \multicolumn{11}{|c|}{ Fair marketing / advertising } \\
\hline \multicolumn{11}{|l|}{$\begin{array}{l}\text { Human Capital } \\
\text { Labor relations }\end{array}$} \\
\hline \multirow{2}{*}{\multicolumn{11}{|c|}{\begin{tabular}{|l|} 
Labor relations \\
Fair labor practices \\
\end{tabular}}} \\
\hline \multicolumn{8}{|l|}{ Fair labor practices } & & & \\
\hline \multicolumn{11}{|c|}{ Employee health, safety / wellbeing } \\
\hline \multicolumn{11}{|l|}{ Diversity / inclusion } \\
\hline \multicolumn{11}{|c|}{ Compensation / benefits } \\
\hline \multicolumn{11}{|c|}{ Recruitment, development / retention } \\
\hline \multicolumn{11}{|c|}{ Business Model / Innovation } \\
\hline \multicolumn{11}{|c|}{ Lifecycle impacts of products / services } \\
\hline \multicolumn{11}{|c|}{ Env., social impacts on assets/ops } \\
\hline \multicolumn{11}{|l|}{ Product packaging } \\
\hline Product quality / sa & & & & & & & & & & \\
\hline Leadership / Gc & & & & & & & & & & \\
\hline Systemic risk mgm't & & & & & & & & & & \\
\hline Accident / safety m & & & & & & & & & & \\
\hline Business ethics/tra & & & & & & & & & & \\
\hline Competitive behavi & & & & & & & & & & \\
\hline Regulatory capture & & & & & & & & & & \\
\hline Materials sourcing & & & & & & & & & & \\
\hline Supply chain mgm't & & & & & & & & & & \\
\hline
\end{tabular}

Source: Sustainability Accounting Standards Board. www.sasb.org

Note: Dark (light) grey color means that for more (less) than $50 \%$ of the industries within the sector the issue is material. White means that the issue is not material for any industry within the sector. To see materiality maps at the industry level that determine whether an issue is material or not for that industry visit www.sasb.org 


\section{Appendix IV}

\section{Example of material and immaterial ESG proposals}

\section{Material ESG proposal}

- In 2011, McDonald's Corporation received a shareholder proposal regarding "Food Safety Concerns" (per the 'Resolution' data field in ISS).

- SASB's Sector-level Materiality Map identifies "Product quality/safety" as a material issue in the Consumption sector (to which McDonald's Corporation belongs).

- This proposal was coded as material.

\section{Immaterial ESG proposal}

- In 2007, Wells Fargo \& Company, the multinational banking and financial services company, received a shareholder resolution to "Set GHG emissions reductions goals".

- SASB's Sector-level Materiality Map does not identify "GHG emissions" as a material issue for the Financials sector (to which Wells Fargo \& Company belongs).

- This proposal was coded as immaterial. 